\title{
Effect of Vitamin D on the Spleen of Adult Male Rats Fed on Diet with High Fat: A Histological and Immunohistochemical Study
}

\section{Original Article}

\author{
Heba Kamal Mohamed
}

Department of Human Anatomy and Embryology, Faculty of Medicine, Assiut University, Egypt

\begin{abstract}
Background: High fat diet (HFD) is the cause of obesity prevalence which is a serious health problem. Vitamin D is considered a very important modulator in cellular inflammation and immune systems.

Aim of the work: To demonstrate the histological changes in the spleen of the adult male rats fed with HFD and to evaluate vitamin D role in counteracting the harmful effects of HFD on the spleen.

Materials and Methods: A total number of 36 male adult albino rats which were classified equally and randomly into three groups as follows; Control group where rats were administered the control diet for a period of 10 weeks, HFD fed group which was administered HFD for 10 weeks and HFD + vitamin D group which was administered HFD concomitantly with vitamin D orally daily for 10 weeks at a dose of $1 \mathrm{ug}(40 \mathrm{IU}) / \mathrm{kg}$. Samples from the spleen were prepared for histological and immunohistochemical study.

Results: The group received HFD revealed marked histological alterations with lymphatic follicles proliferation. Most splenic cells showed degenerative changes. Deposition of hemosidrin pigments, markedly dilated blood sinusoids and blood extravasation were observed. CD86 had a strong cytoplasmic expression in dendritic cells. Moreover, cytoplasmic immune reaction for iNOS and caspase-3 in the white and red pulps of the spleen was intense. Vitamin D co-adminstration greatly preserved the histological and immunohistochemical structure of the spleen.

Conclusion: This study suggests that vitamin D has a role in splenic protection and can attenuate the deleterious effects commonly detected in the spleen and immune system in case of obesity induced by HFD.
\end{abstract}

Received: 20 May 2019, Accepted: 20 June 2019

Key Words: CD86, obesity, spleen, vitamin D.

Corresponding Author: Heba K. Mohamed, PhD, Department of Human Anatomy and Embryology, Faculty of medicine, Assiut University, Assiut, Egypt, Tel.: +20 1001016547, E-mail: hebaelgamae73@yahoo.com

ISSN: $1110-0559$, Vol. 42, No. 4

\section{INTRODUCTION}

Obesity is a widely spread serious health problem. HFD is responsible for obesity prevalence which has recorded epidemic levels in most of the developed countries ${ }^{[1]}$.

Obesity is characterized by severe disorder of metabolism and it is multifactorial disease involving genetics, behavior and endocrine factors, with direct contribution to systemic inflammation ${ }^{[2]}$. High carbohydrate or fat diet, decrease physical activity and fast food consumption, are considered environmental factors which incorporated in the occurrence of obesity ${ }^{[3]}$.

The consumption of a HFD is considered a risk factor for induction of obesity not only in humans but also in rats and mice as a result of increased energy intake and efficient energy storage ${ }^{[4]}$. So HFD feeding for a long period is considered a suitable obesity model in rats for detection of the underlying mechanisms of obesity occurrence and progression $^{[5]}$.
Obesity is considered the prominent risk factor for the development of the syndrome of multiple organ dysfunction and obesity consequences including high risk of pulmonary dysfunction, diabetes and metabolic syndrome ${ }^{[6]}$. The advance in organ damage was promoted by augmented inflammation in adipose and other tissues because obesity is a chronic low-grade inflammatory disease as most of the obese patients had shown increased levels of interleukin-6 (IL-6) and tumor necrosis factoralpha (TNF- $\alpha)$, both are proinflammatory cytokines and markers of inflammation ${ }^{[7,8]}$. Some proinflammatoryrelated cytokines are produced in the obese state from macrophage-infiltrated white adipose tissue (WAT) ${ }^{[9]}$. Increase in the adipose tissue can result in a significant reduction in the activity of antioxidant enzymes ${ }^{[10,11]}$.

Some studies reported a link between obesity and some functional changes in the immune system ${ }^{[12]}$. Some cells like dendritic cells (DCs) and macrophages are responsible for innate immunity as they are responsible for cytokines 
production. $\mathrm{T}$ and B-cells activity can induce adaptive immunity. Activation of innate immunity is critical to adaptive immunity initiation ${ }^{[13]}$.

The spleen plays a main role in immunity as it is considered the largest lymphoid organ ${ }^{[14]}$. The spleen can link between adaptive and innate immunities, as about $15 \%$ of the fixed macrophages in the body are contained in it, in addition to a large number of lymphocyte ${ }^{[15]}$. Moreover, obese rats showed decreased proinflammatory cytokines gene expression, such as IL- 6 and TNF- $\alpha$ of the spleen ${ }^{[14]}$.

Calcitriol, or 1,25-Dihydroxycholecalciferol, is the vitamin $\mathrm{D}$ active form, which can regulate gene expression which is incorporated in the function of immune system ${ }^{[16]}$. Interestingly, Vitamin D has beneficial effect in reducing the inflammatory profile and body fat ${ }^{[17,18]}$, Moreover, it has neuroprotective effects against HFD- induced neuronal $\operatorname{loss}^{[19]}$.

The aim of this work was to evaluate the effects of obesity induced by fatty diet on the histological structure of the spleen and to detect the possible vitamin D role in protection.

\section{MATERIALS AND METHODS}

\section{Chemicals}

- Vitamin D (Cholecalciferol) was obtained via Sigma-Aldrich Co., USA as a powder. Corn oil was used to dissolve vitamin D supplements.

- Caspase-3 and inducible nitric oxide synthase (iNOS) were obtained from Thermo Fisher Scientific, USA.

- CD86 was purchased from Novus Biologicals, USA. Other chemicals were of the highest quality available.

\section{Animals}

Thirty-six adult male albino rats (180-200 gm) were used. Animal House in Faculty of Medicine, Assiut University was the source of these animals. All animals were held in clean cages with proper ventilation for 1 week before the beginning of the experiment. Food and water ad libitum were given to animals at the temperature of room. They were maintained in a controlled light room with 12 hours dark and 12 hours light photoperiod (12:12light/ dark cycle). The experimental protocols were performed on the basis of the guidelines accepted internationally for Laboratory Animals Use and Care.

\section{Experimental Diets}

In this experiment, two different diets (control and HFD) were prepared in the Animal Nutrition Department, Faculty of Veterinary Medicine, Assiut University, Assiut. Supply of the two diets to the respective groups was without any change throughout the experimental period. Diets were designed according to National Research Council (NRC) recommendations ${ }^{[20]}$ and Burgmair et al. ${ }^{[21]}$ to meet the rats' nutritional requirements. The control diet was formulated from $0.5 \%$ common salt, $0.5 \%$ premix, $2 \%$ soybean, $4 \%$ sunflower oil, $22 \%$ wheat bran and $71 \%$ corn to supply each rat with $7.37 \%$ fat, $10.58 \%$ crude protein and $69.65 \%$ carbohydrates. This diet has metabolizable energy of about $3274 \mathrm{kcal} / \mathrm{kg}$. The HFD was formulated from $0.5 \%$ wheat bran, $0.5 \%$ common salt, $0.5 \%$ premix, $4 \%$ molasses, $4.5 \%$ soy-bean, $22 \%$ mixture of sunflower oil and olive oil and $68 \%$ corn to supply each rat with $8.27 \%$ crude protein, $24.64 \%$ fat and $55.95 \%$ carbohydrates. The metabolizable energy of this diet was $4645.25 \mathrm{kcal} / \mathrm{kg}$.

\section{Experimental design}

A total number of 36 male adult albino rats were randomly classified into three equal groups ( $\mathrm{n}=12$ for each group) as follows:-

1. Group I (Control group): rats received the control diet for 10 weeks in this group;

2. Group II (High-fat diet group): rats received 10 weeks HFD for the induction of obesity in this group $^{[22]}$;

3. Group III (High-fat diet + vitamin D group): rats administered HFD concomitantly with 1 ug (40 $\mathrm{IU}) / \mathrm{kg}$ vitamin $\mathrm{D}^{[23]}$ orally for 10 weeks daily.

All rats were sacrificed by cervical decapitation at the end of experimental period, then the spleens dis $\neg$ sected out and processed for histological and immunohistochemical study.

\section{Histological study}

Specimens of the spleen were cut into two parts for each group. Some pieces of the first part were fixed in $10 \%$ formalin, processed for obtaining paraffin sections of 5 um thickness. These sections were HandE and immunohistochemically stained for Light microscopic study ${ }^{[24]}$.

For electron microscopic study, the second part was divided into small pieces (1X1 mm thickness) and fixed in $4 \%$ glutaraldehyde and then in $1 \%$ osmium tetroxide. Semithin sections (0.5-1 um) were obtained and stained with toluidine blue. Ultrathin sections $(50-80 \mathrm{~nm})$ were then cut, contrasted with uranyl acetate and lead citrate ${ }^{[25]}$. Examination and photographing of the sections was done by Jeol-JEM-100 CXII; transmission electron microscope (Tokyo, Japan) at Assiut University electron microscopic unit.

\section{Immunohistochemical study}

For caspase-3 (rabbit polyclonal antibody), CD86 (mouse monoclonal antibody) and inducible nitric oxide synthase (polyclonal rabbit anti-iNOS, immunohistochemistry, paraffin-embedded sections of the splenic tissues of different groups and of a positive control were sectioned into a $5 \mu \mathrm{m}$ thickness on slides which are positively charged and undergo $24 \mathrm{~h}$ incubation in an oven at $42^{\circ} \mathrm{C}$. Slides were treated with hydrogen peroxide 
$\left(\mathrm{H}_{2} \mathrm{O}_{2}\right) 0.2 \%$ in PBS for endogenous peroxidase blockage for $30 \mathrm{~min}$. Sections were then overnight incubated at $4{ }^{\circ} \mathrm{C}$ with caspase- 3 primary antibody $(1: 100)^{[26]}$, other sections incubated against CD86 (1:100 dilution) which was used for splenic CD86 detection ${ }^{[27]}$, while other sections incubated against iNOS (diluted 1:100) ${ }^{[28]}$. The universal kit used was biotinylated secondary antibodies. Visualization of the immunoreactivity was done using a chromogen of $0.05 \%$ diaminobenzidine and counterstaining of sections with Mayer's hematoxylin was done. Mounting by DPX was performed. For Negative controls, the same protocol was followed, but without the primary antibody use. The positive controls for the immunohistochemical markers used were tonsils for caspase- 3 and CD86, and lungs for iNOS.

\section{RESULTS}

\section{Light microscopic results}

\section{Hematoxylin and eosin (HandE) and toluidine blue} stains

Spleen tissue sections from the control rats (group I) showed normal architecture of the two components of the parenchyma of the spleen (splenic pulp) which are the white and red pulps. The white pulp is occupied by the central arteriole. Lymphatic follicles containing lymphocytes were present. The lymphocytes were closely packed. The red pulp is demarcated from the white pulp by the marginal zone which is delimited from the lymphatic follicles by the marginal sinus. Cell cords networks called splenic cords constitute the red pulp and were separated by vascular sinuses with bulged nuclei. RBCs, plasma cells containing eccentric nuclei, small and large lymphocytes were noticed (Figures 1, 2, 8 and 9).

In HFD group (group II), marked histological alterations were detected. Lymphatic follicles proliferation was observed. Most of the white pulp cells had changes of degeneration in the form of irregular dense nuclei and pale vacuolated cytoplasm. Empty wide spaces in between the cells and apoptotic bodies were seen. The central arteriole had degenerated areas in its wall. The red pulp of the spleen revealed loss of architecture and that the majority of lymphocytes had dark irregular nuclei with heterogenous or vacuolated cytoplasm. Cytoplasmic deposition of hemosidrin pigments in many cells, markedly dilated blood sinusoids and blood extravasation were noticed (Figures 3-5 and 10-12).

As regards group treated with vitamin D (group III), Splenic sections showed focal affection. Normal distribution of the lymphatic follicles was observed. Both of the white and red pulps revealed nearly normal cellular architecture with increase cellularity and variability in size, shape and cell nuclei density. Slight empty spaces among the cells were observed. Slightly dilated sinusoids and scanty hemosidrin deposition were noticed (Figures 6, 7 and 13).

\section{Immunohistochemical results}

The positive immunohistochemical reaction for caspase-3 appeared as brown cytoplasmic staining (index for the degree of apoptosis). Caspase-3 immunostained sections showed a weak cytoplasmic immunoreactivity in the splenic cells of the white and red pulps in group I (Figure 14). In group II, an intense cytoplasmic immune reaction for caspase-3 was observed in the white and red pulp cells (Figure 15). Group III revealed a slight cytoplasmic immune reaction for caspase- 3 in the splenic cells which is nearly as control (Figure 16).

Splenic sections immunostained with dendritic cell (DC) antibody (CD86) showed positive reaction in DC cytoplasm in the white pulp and marginal zone of group I. The cytoplasmic reaction appeared in the form of granules with dark brown colour (Figure 17). Group II showed a strong expression of CD86 (Figure 18). In group III, the reaction intensity was reduced and became nearly similar to control (Figure 19).

The positive results for the iNOS immune reaction (marker for oxidative stress) were indicated by brown coloration of the cytoplasm. iNOS immunostained sections showed a weak cytoplasmic immune reaction in the splenic cells of the white and red pulps in group I (Figure 20). A strong positive cytoplasmic immunoreactivity to iNOS was detected in the splenic cells in group II (Figure 21). Group III showed moderate expression of iNOS immunoreactivity which is more or less similar to control (Figure 22).

\section{TEM (Transmission Electron microscopic) results}

EM examination of the spleen in group I revealed that the white splenic pulp was formed of numerous lymphocytes. Small lymphocytes showed condensed chromatin pattern in their nuclei and enclosed by a thin cytoplasmic rim. Large lymphocytes had euchromatic nuclei and a nucleolus could be detected. Their cytoplasm contained few cisternae of rough endoplasmic reticulum (rough ER) and few small rounded mitochondria (Figure 23). The splenic marginal zone contained plasma cells, lymphocytes and DCs. The plasma cells appeared with a large eccentric nucleus containing coarse heterochromatin alternating with euchromatin. Their cytoplasm revealed well developed numerous cisternae of rough ER and mitochondria (Figure 24). DCs revealed many cytoplasmic processes in contact with lymphocytes. These cells were marked by their electron lucency and eccentric nuclei. Their cytoplasm contained rough ER, mitochondria, electron dense bodies and abundant ribosomes (Figure 25). The red pulp contained macrophages with a large oval nucleus and irregular outline. Well developed Golgi complex, mitochondria, rough ER, multiple phagosomes, and lysosomal bodies were observed in the cytoplasm (Figure 26).

Ultrathin sections in the group fed on diet with high fat showed extensive affection of most cells of the spleen. Nuclei of lymphocytes revealed peripheral chromatin margination and many coarse clumps of heterochromatin. 
Dilated cisternae around the nucleus were observed. Their cytoplasm showed increased density with hardly identified organelles (Figure 27). Plasma cell had eccentric nucleus with increased heterochromatin and dilated perinuclear cisternae. Markedly dilated rough ER, vacuolations and mitochondria which was swollen with distorted cristae or electron dense mitochondria were noticed in the cytoplasm. RBCs were detected (Figure 28). The dendritic cell appeared with ill defined plasma membrane, a heterochromatic nucleus and vacuolated rarified cytoplasm containing vacuolated mitochondria and dilated rough ER. The presence of RBCs was noticed beside the cell (Figures 27 and 29). Macrophages revealed a large electron dense eccentric nucleus with irregularity of the nuclear envelope and dilated perinuclear cisternae. The cytoplasm showed multiple phagosomes, lysosomal bodies with heterogenous contents, markedly dilated rough endoplasmic reticulum, swollen electron dense mitochondria and numerous vacuoles (Figure 30).

Ultrathin splenic sections in the group treated with vitamin D exhibited minimal affection of its cells. Most cells revealed nearly similar ultrastructural appearance to control. Lymphocytes showed more or less similarity to control. Small lymphocytes appeared with nuclear chromatin condensation and a thin cytoplasmic rim which surrounded the nucleus. Large lymphocytes had a large euchromatic nucleus. Their cytoplasm contained small mitochondria and rough ER (Figure 31). Plasma cell appeared nearly similar to control group with a large eccentric nucleus containing coarse heterochromatin alternating with euchromatin. The cytoplasm revealed few dilated rough ER cisternae, mitochondria and Golgi complex. Vacuolated areas and RBCs can be noticed (Figure 32). The dendritic cell had a large eccentric nucleus with many cytoplasmic processes in contact with lymphocytes. Its cytoplasm revealed mitochondria, slightly dilated rough ER, minute vacuoles, abundant ribosomes and electron dense bodies. Ill defined cell membrane with cytoplasmic processes in contact with lymphocytes was noticed (Figure 33). Macrophages showed irregular outline and an eccentric large nucleus. Multiple lysosomal bodies with heterogenous contents, mitochondria and minute vacuolations were noticed in the cytoplasm (Figure 34).

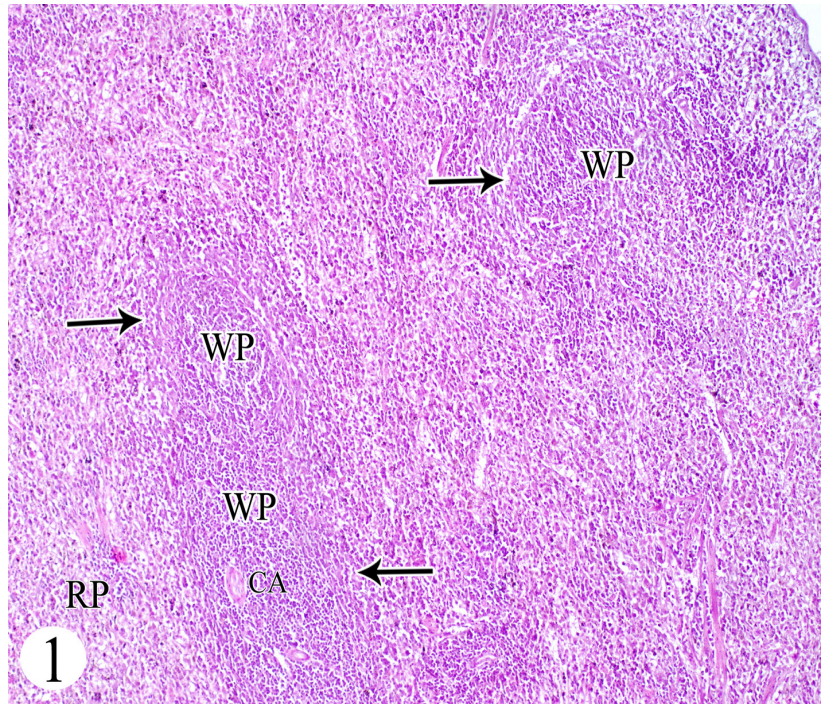

Fig. 1: A photomicrograph of a control rat splenic section (group I) showing normal architecture of the splenic pulps which are the white (WP) and the red (RP) pulps. Lymphatic follicles (arrows) and central arteriole (CA) are noticed in the white pulp. $\mathrm{H}$ and E, X100

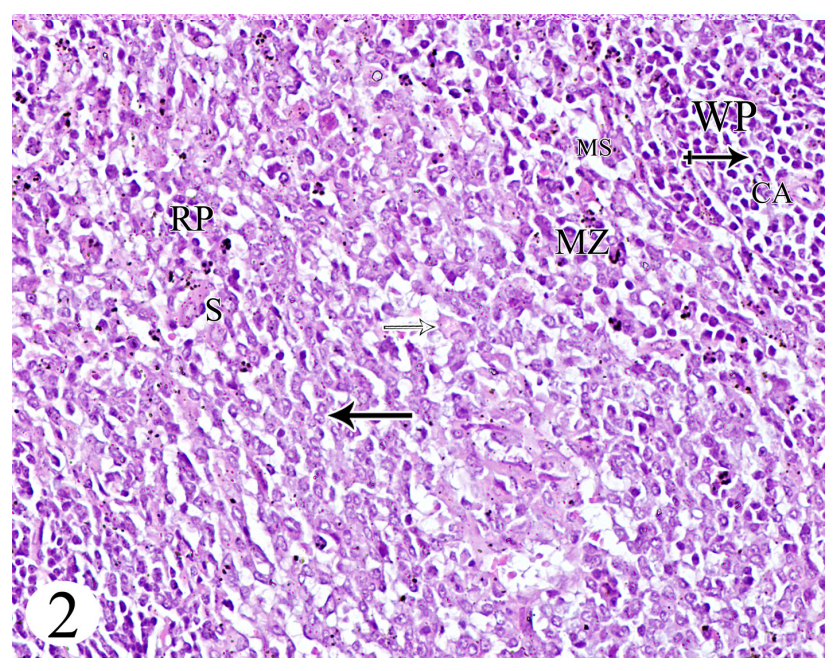

Fig. 2: A photomicrograph of a rat splenic section (group I) showing the white pulp (WP) which is formed by closely packed lymphocytes (crossed arrow) and contains central arteriole (CA). The red pulp (RP), marginal zone (MZ) and marginal sinus (MS) are noticed. The red pulp is formed of splenic cords which are separated by the blood sinusoids (S). It contains lymphocytes (arrow) and RBCs (open arrow). HandE, X400. 


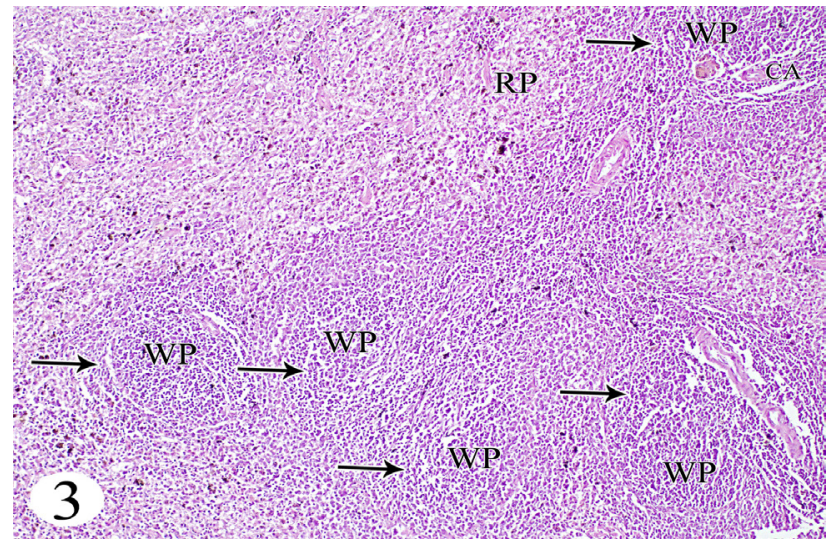

Fig. 3: A photomicrograph of a splenic section in rat fed with high fat diet (group II) showing the white (WP) and the red (RP) pulps. Note lymphatic follicles proliferation (arrows) and the central arteriole (CA). HandE, X100.

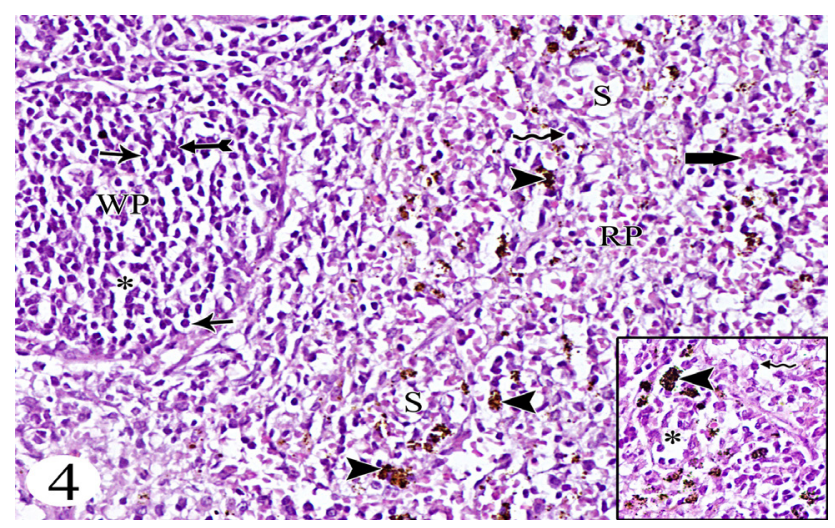

Fig. 4: A photomicrograph of a rat splenic section (group II) showing that most of the white pulp (WP) cells have degenerative changes in the form of dense irregular nuclei and dense cytoplasm (tailed arrow) or pale vacuolated cytoplasm (short arrows). Note empty wide spaces in between the cells (asterisk). The red pulp (RP) reveals lymphocytes with dark irregular nuclei (wavy arrow) and vacuolated cytoplasm. Cytoplasmic deposition of hemosidrin pigments in many cells (arrow heads) and blood extravasation (thick arrow) are observed. Note dilated blood sinusoids (S). Inset: showing densely stained cells with vacuolated cytoplasm (wavy arrow) and deposition of hemosidrin pigments (arrow head). Note empty spaces (asterisk). HandE, X400

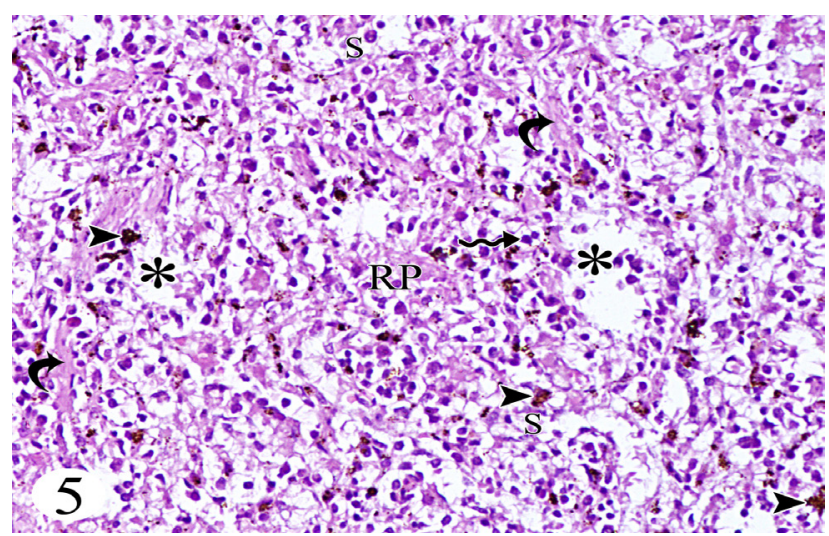

Fig. 5: A photomicrograph of a rat splenic section (group II) showing markedly dilated blood sinusoids (S) and fibrinoid material (curved arrows). Considerable hemosidrin pigments deposition was noticed (arrow heads). Wide spaces (asterisks) and cells with densely stained nuclei (wavy arrow) are observed. HandE, X400.

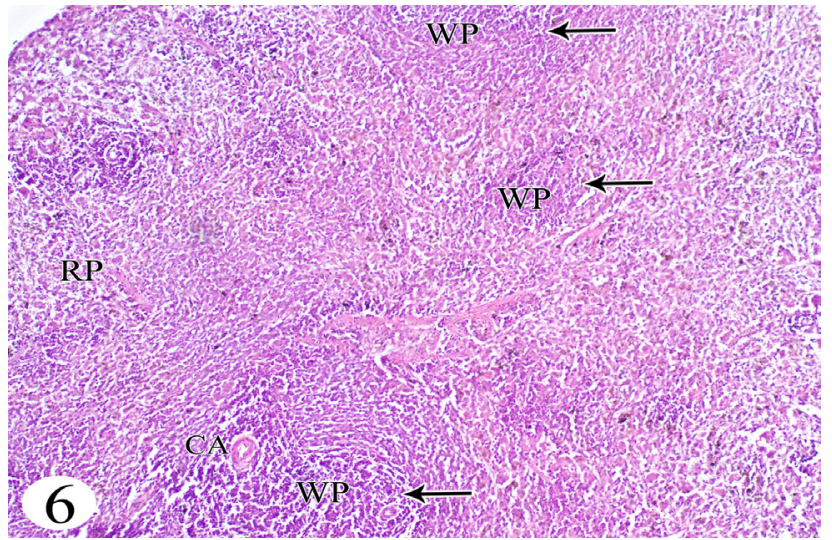

Fig. 6: A photomicrograph of a splenic section in rat treated with vitamin D (group III) showing the white pulp (WP) with its central arteriole (CA) and the red pulp (RP). Note the distribution of lymphatic follicles (arrows). HandE, X100.

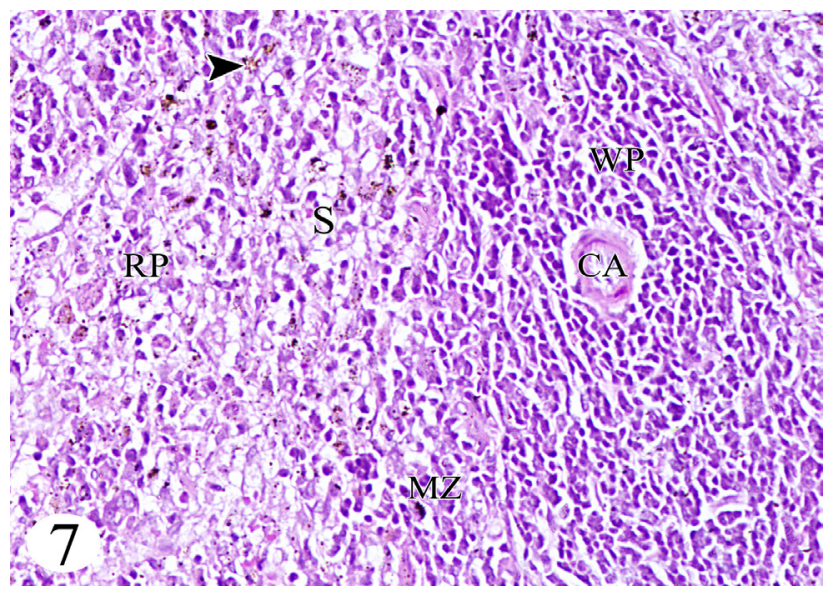

Fig. 7: A photomicrograph of a rat splenic section (group III) showing the white pulp and the central arteriole (CA). Note the marginal zone (MZ) and the red pulps (RP). Slightly dilated sinusoids (S) and scanty hemosidrin deposition (arrow head) are noticed. HandE, X400.

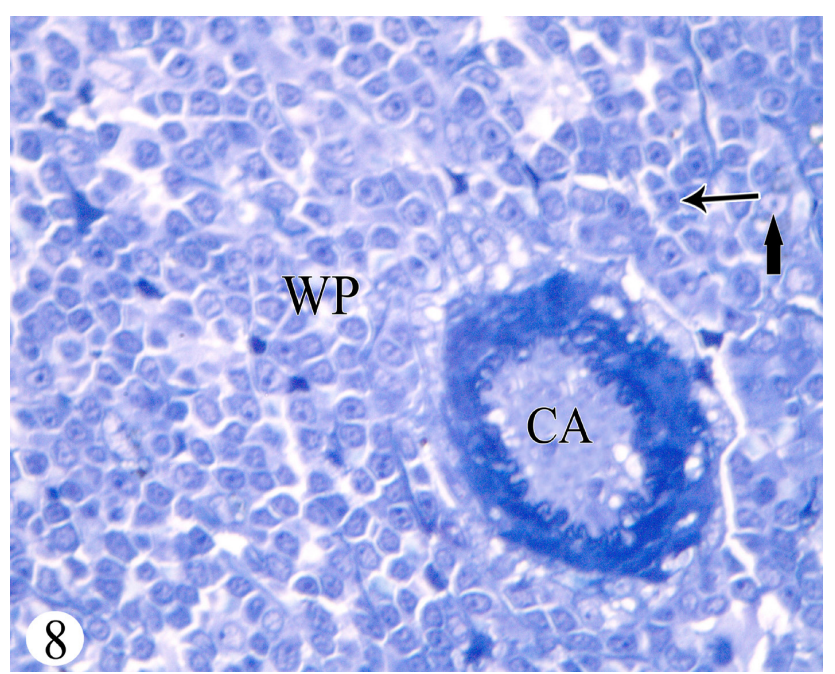

Fig. 8: A photomicrograph of a rat splenic semithin section (group I) showing the white pulp (WP) and the central arteriole (CA). Small lymphocytes (thin arrow) with dense nuclei are observed. Note large lymphocytes (thick arrow) which appear lightly stained with vesicular nuclei. Toluidine blue, X1000. 


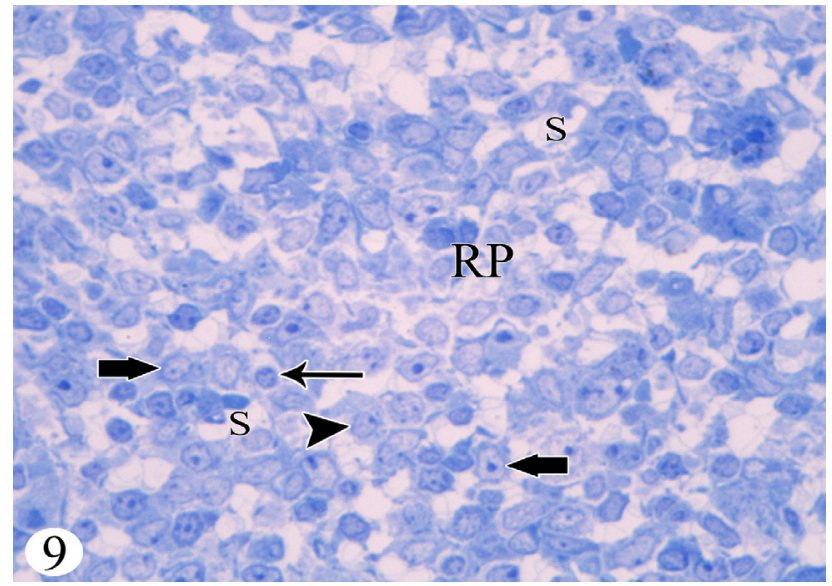

Fig. 9: A photomicrograph of a rat splenic semithin section (group I) showing the splenic (RP) and vascular sinuses (S). Note small lymphocytes (thin arrow), large lymphocytes (thick arrow) and plasma cells with eccentric nuclei (arrow head). Toluidine blue, X1000.

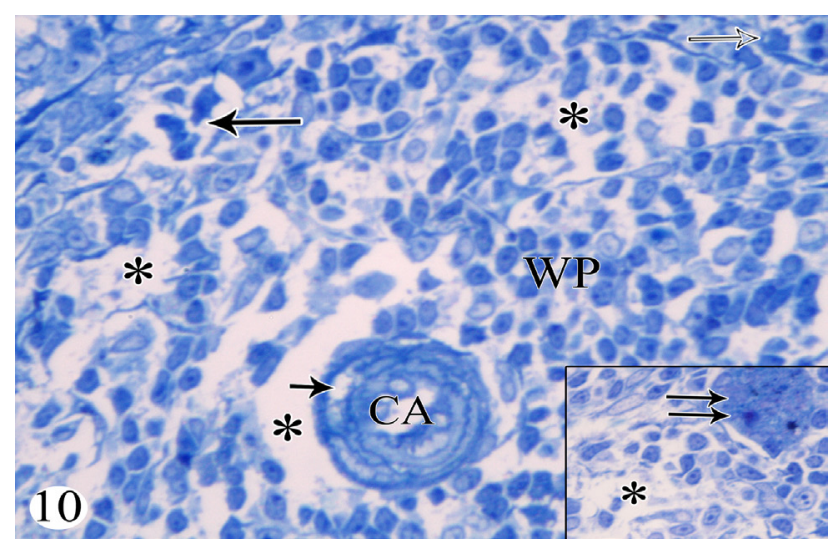

Fig. 10: A photomicrograph of a rat splenic semithin section (group II) showing the white pulp (WP) with numerous wide empty spaces (asterisks). Degenerated cells with irregular dense nuclei and cytoplasmic vacuolation (arrow) or deeply stained nuclei (open arrow) are noticed. Note degenerated areas (short arrow) in the wall of the central arteriole (CA). Inset: shows empty spaces between the cells (asterisks) and apoptotic body (double arrow) within the white pulp. Toluidine blue, $\mathrm{X} 1000$.

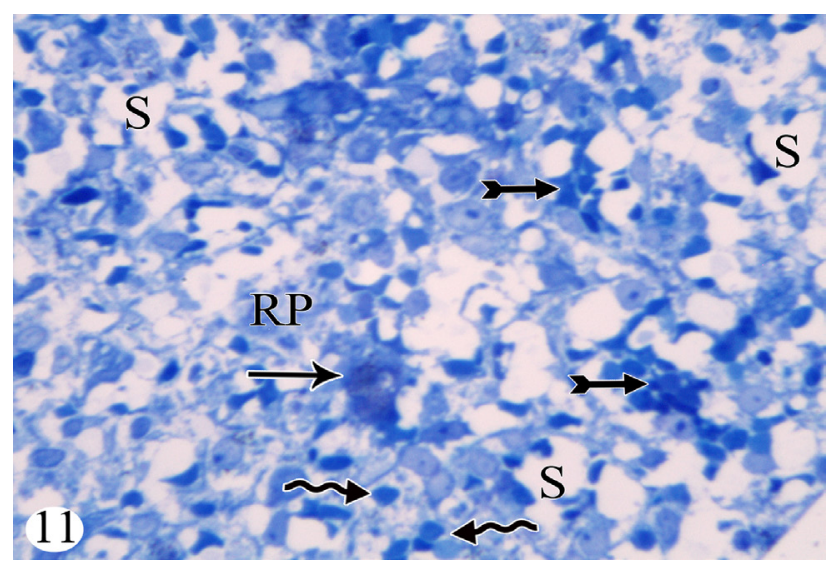

Fig. 11: A photomicrograph of a rat splenic semithin section (group II) showing the red pulp (RP) which reveals markedly dilated blood sinusoids (S) with extravasation of blood in the interstitial tissue (tailed arrows). Note some degenerated cells with deeply stained irregular nuclei (wavy arrows). Large irregular cells with dense heterogenous cytoplasm and dense nuclei are noticed (arrow). Toluidine blue, X1000.

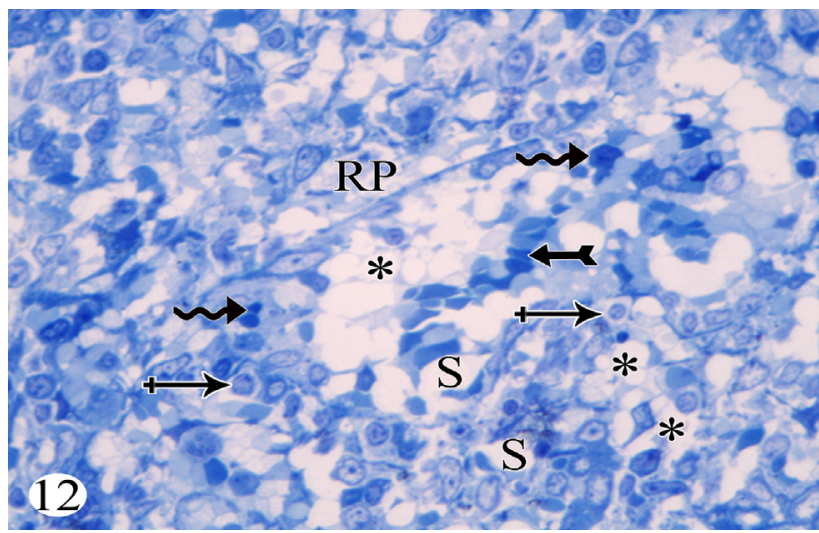

Fig. 12: A photomicrograph of a rat splenic semithin section (group II) showing the red pulp (RP) with marked cytoplasmic vacuolations (crossed arrows) and many cells with irregular nuclei (wavy arrows). Note markedly dilated blood sinusoids (S) with extravasation of blood (tailed arrow). Empty wide spaces (asterisks) were present. Toluidine blue, X1000.

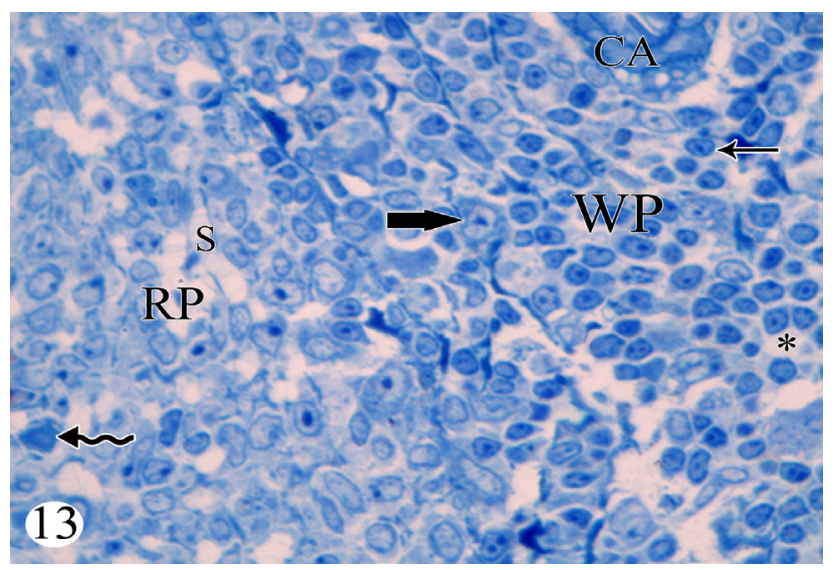

Fig. 13: A photomicrograph of a rat splenic semithin section (group III) showing the white (WP) and red pulps (RP). Small lymphocytes with dense nuclei (thin arrow) are noticed. Large lymphocytes with large vesicular nucleus (thick arrow) are observed. Note the presence of slight empty spaces (asterisk) and the central arteriole (CA). The red pulp shows few cells with dense nuclei (wavy arrows) and slightly dilated blood sinusoids (S). Toluidine blue, X1000.

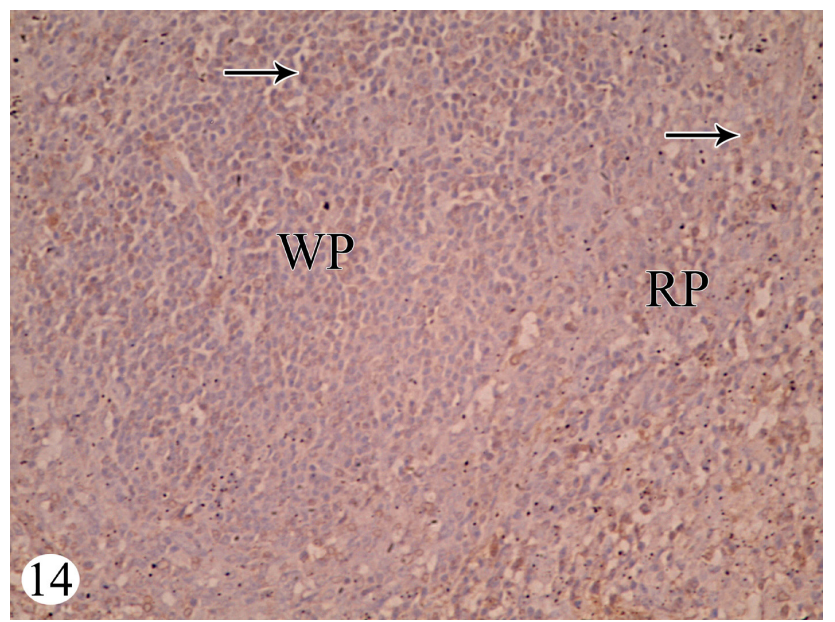

Fig. 14: A photomicrograph of a rat splenic section (group I) immunostained with caspase-3 showing a weak positive immunoreactivity (arrows) in the cytoplasm of the white (WP) and red (RP) pulp cells which appears as a brown coloration. Caspase 3, X400. 


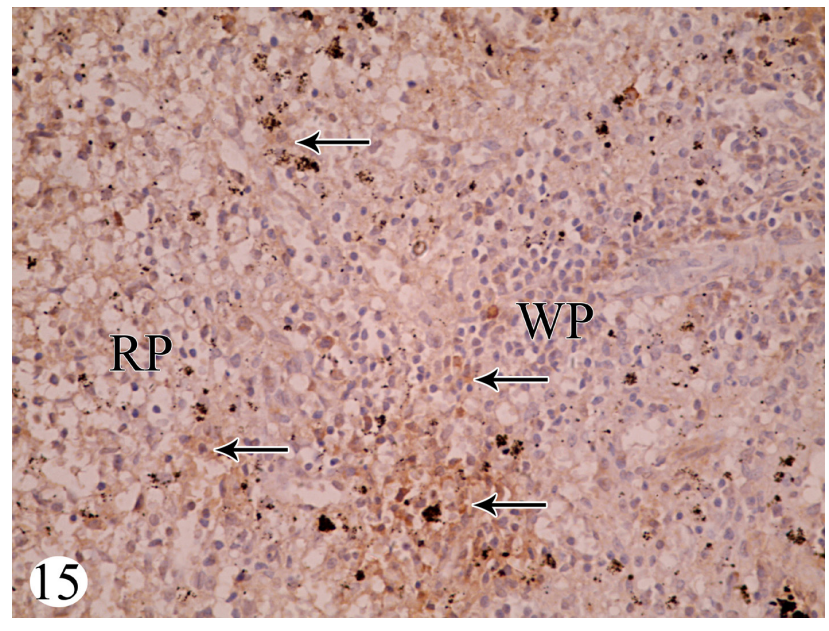

Fig. 15: A photomicrograph of a rat splenic section (group II) showing an intense cytoplasmic immune reaction (arrows) for caspase-3 in the cells of the splenic white (WP) and red (RP) pulps. Caspase 3, X400.

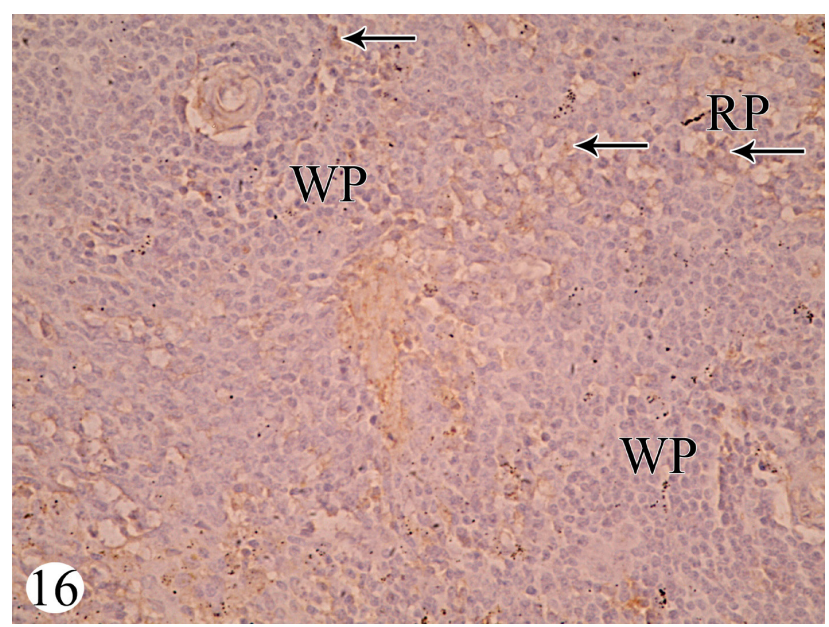

Fig. 16: A photomicrograph of a rat splenic section (group III) showing a slight cytoplasmic immunoreactivity (arrows) for caspase-3 in the cells of the white (WP) and red pulps (RP). Caspase 3, X400.

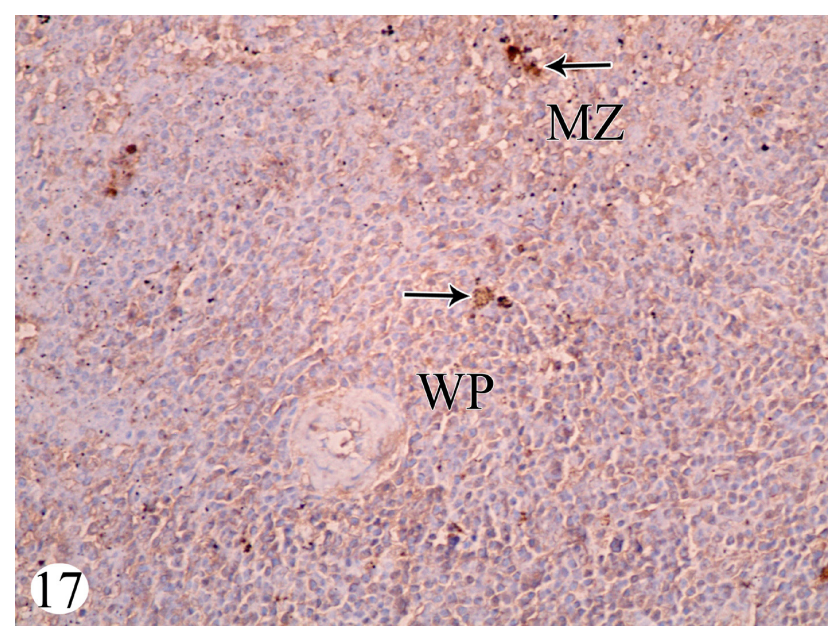

Fig. 17: A photomicrograph of a a rat splenic section (group I) immunostained with dendritic cell (DC) antibody (CD86) showing positive reaction as dark brown granules (arrows) in DC cytoplasm in the white pulp (WP) and the marginal zone (MZ). CD86, X400.

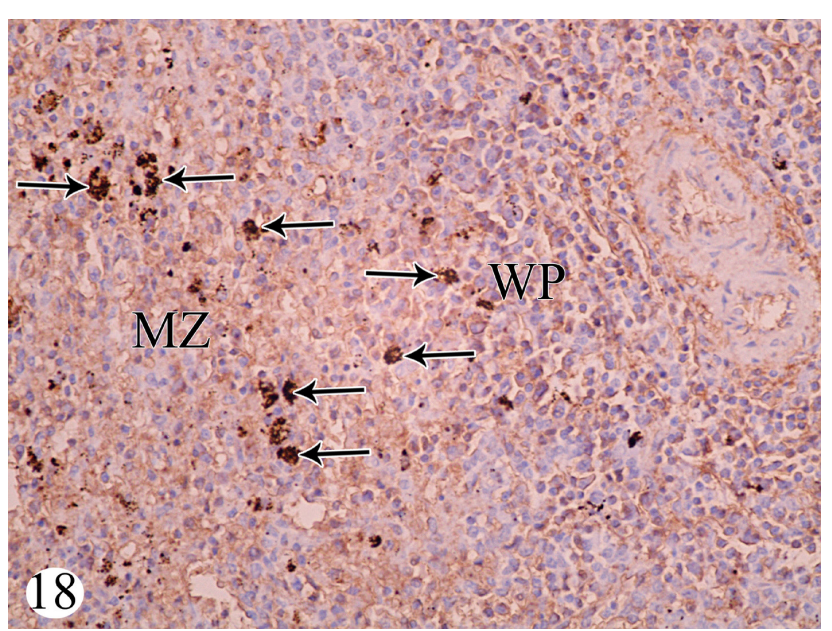

Fig. 18: A photomicrograph of a rat splenic section (group II) showing strong CD86 expression in DC (arrows) in the marginal zone (MZ) and white pulp (WP). CD86, X400.

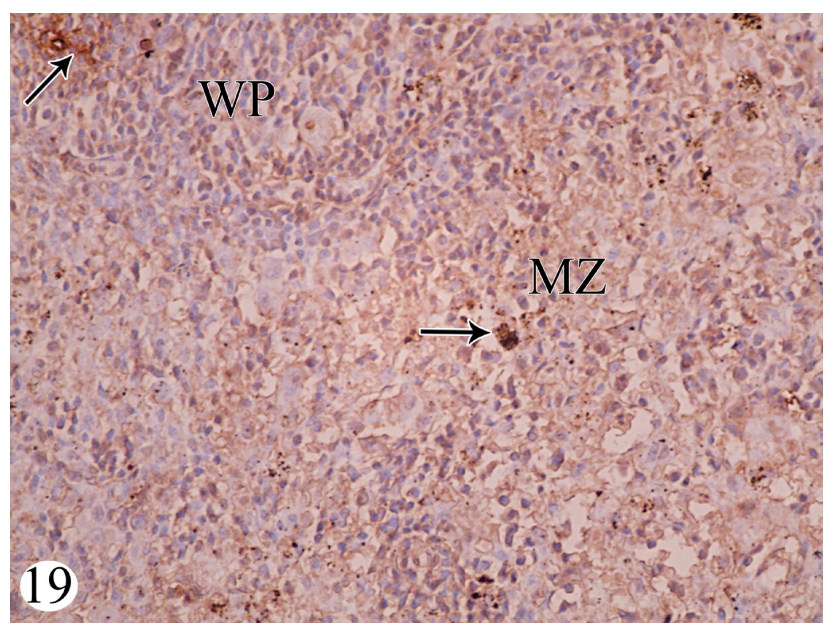

Fig. 19: A photomicrograph of a rat splenic section (group III) showing low intensity of the expression of CD86 in DC (arrows) in the white pulp (WP) and the marginal zone (MZ). CD86, X400.

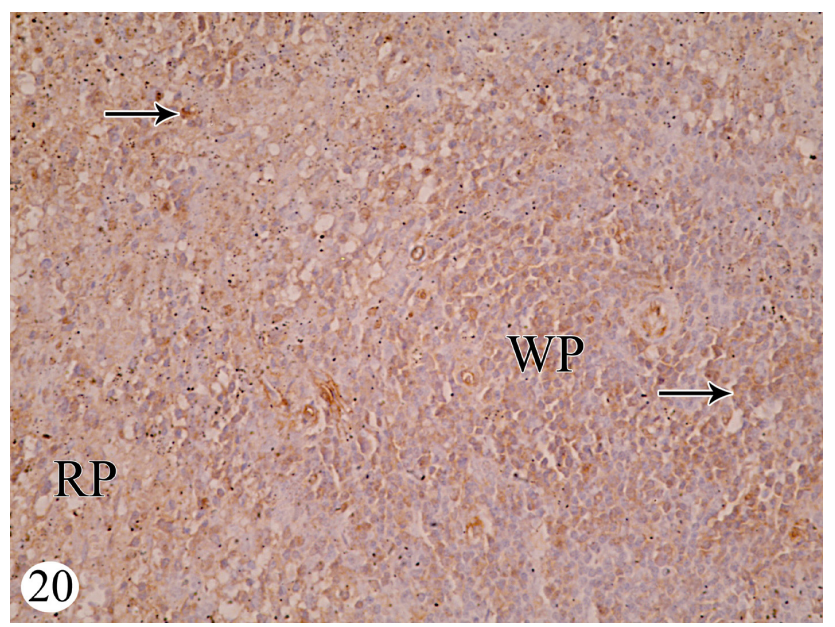

Fig. 20: A photomicrograph of a rat splenic section (group I) showing a weak brownish cytoplasmic immune reaction (arrows) to iNOS in the white (WP) and red (RP) pulp cells. iNOS, X400. 


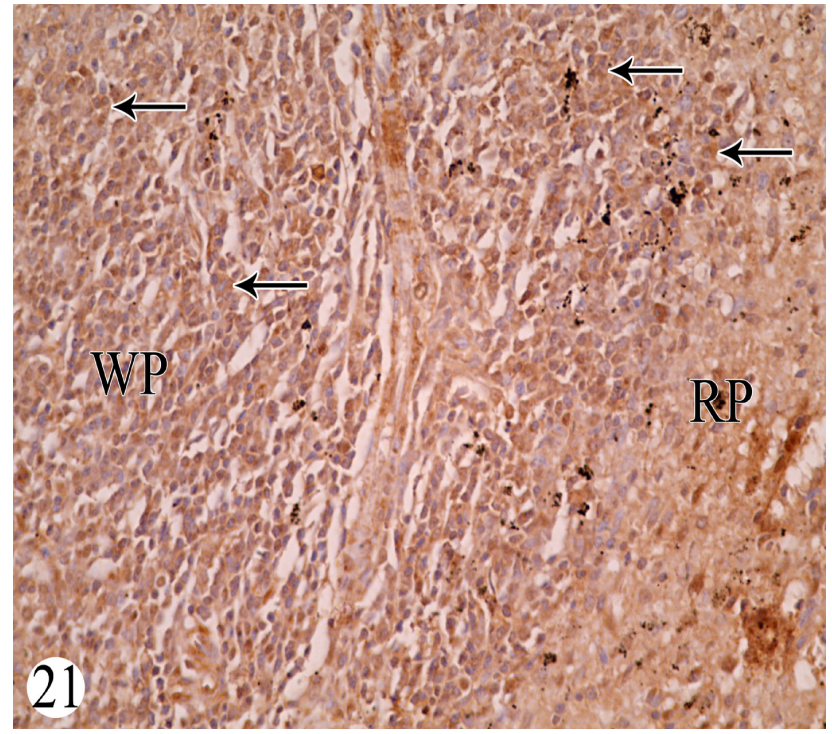

Fig. 21: A photomicrograph of a rat splenic section (group II) showing a strong positive cytoplasmic immunoreactivity to iNOS (arrows) in the white (WP) and red (RP) pulp cells. iNOS, X400.

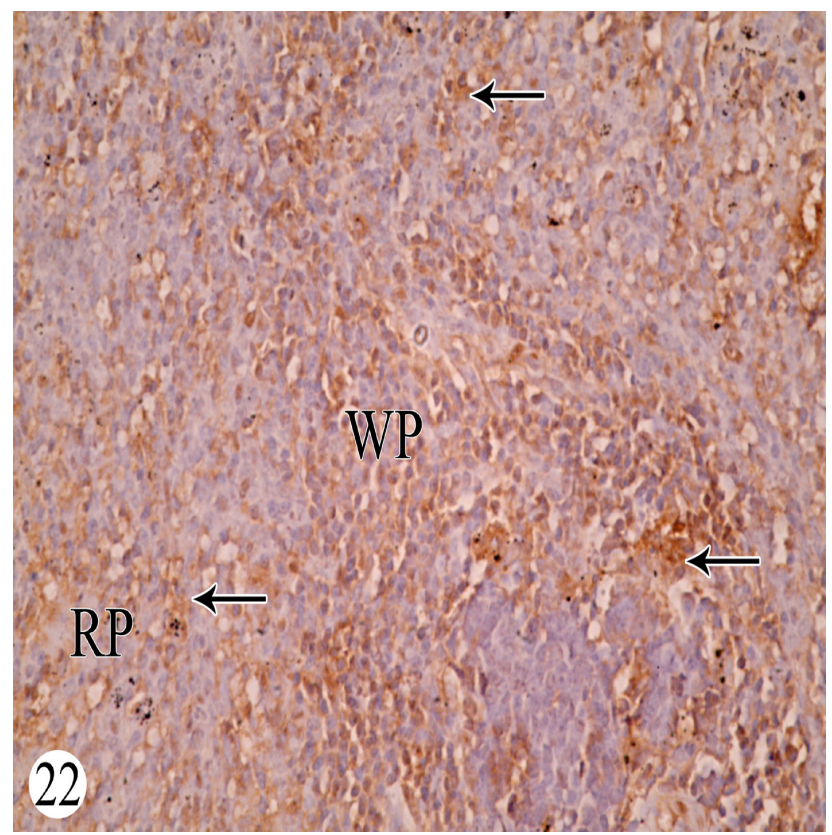

Fig. 22: A photomicrograph of a rat splenic section (group III) showing a moderate immunohistochemical reaction to iNOS (arrows) in the white (WP) and red (RP) pulp cells. iNOS, X400.

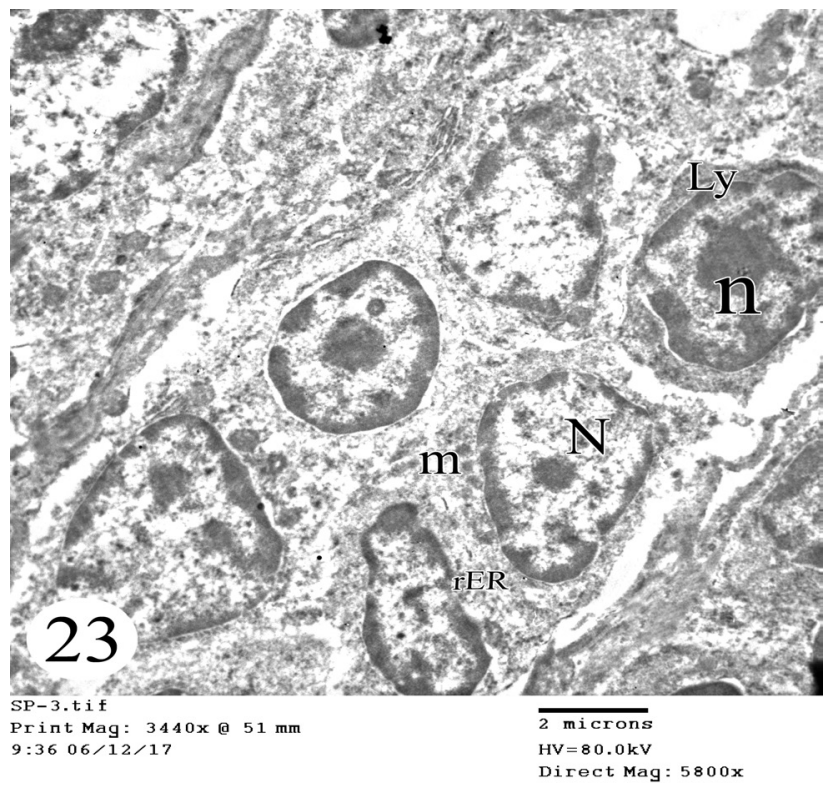

Fig. 23: TEM of lymphocytes (group I) showing some small lymphocytes (Ly) with nuclei $(\mathrm{n})$ revealing condensed pattern of chromatin and a thin cytoplasmic rim surrounding it. Note large lymphocytes having euchromatic nucleus $(\mathrm{N})$. The cytoplasm contains small rounded mitochondria $(\mathrm{m})$ and rough ER (rER). TEM, X5800.

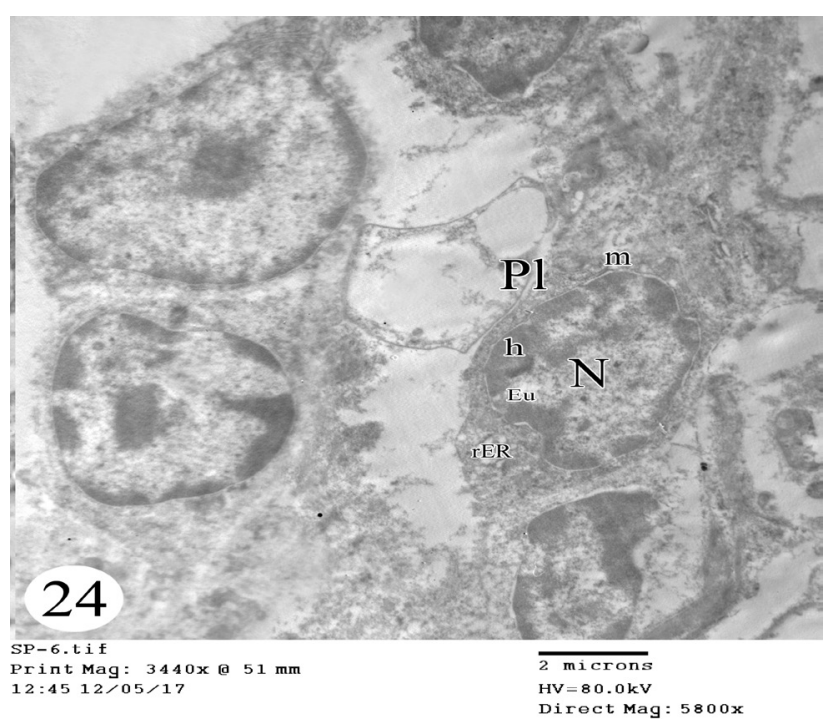

Fig. 24: TEM of plasma cell (Pl) (group I) showing a large eccentric nucleus containing coarse heterochromatin (h) alternating with euchromatin (Eu). Its cytoplasm reveals numerous rough ER cisternae (rER) and mitochondria (m). TEM, X5800. 


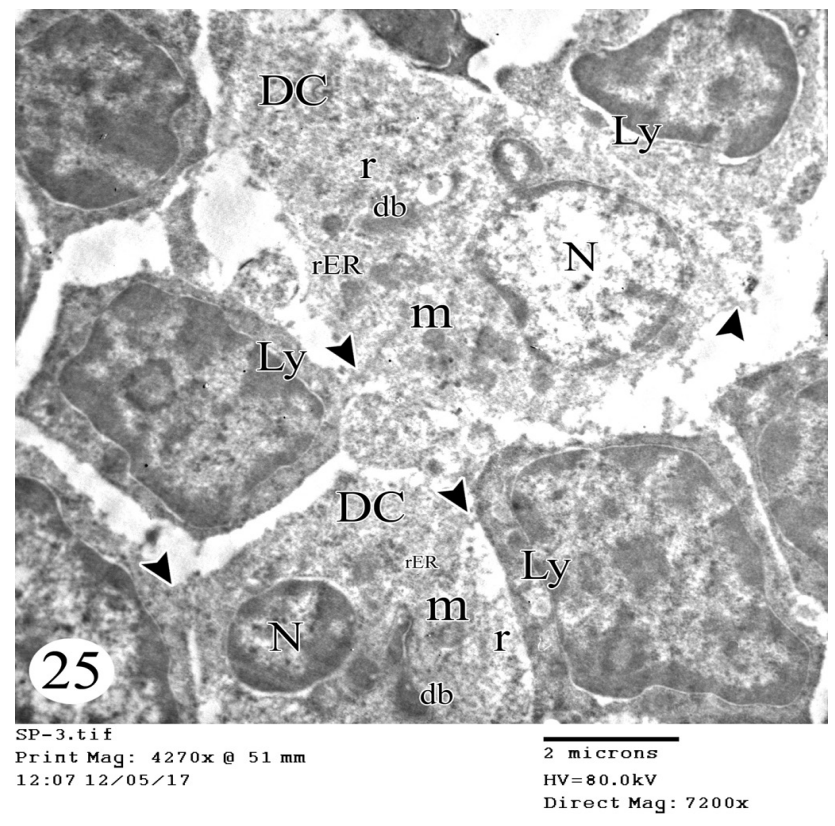

Fig. 25: TEM of DCs (group I) showing many cytoplasmic processes (arrow heads) in contact with lymphocytes (Ly). These cells show electron lucency and eccentric nuclei $(\mathrm{N})$. The cytoplasm reveals abundant ribosomes (r), rough ER (rER), mitochondria (m) and dense bodies (db). TEM, X7200.

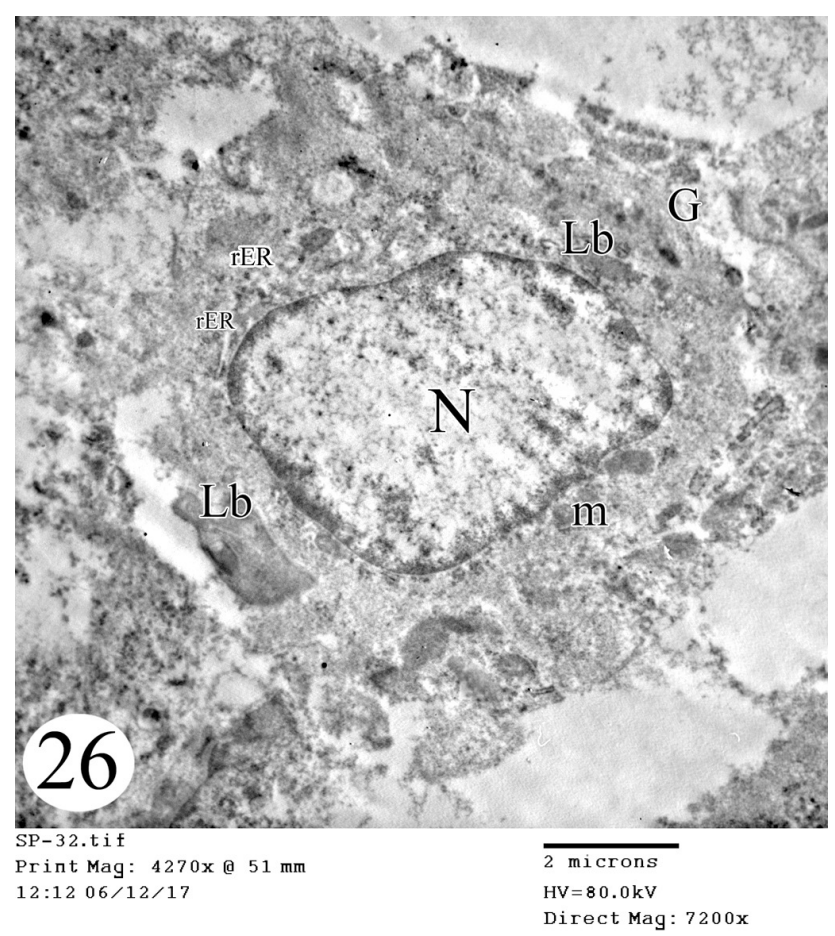

Fig. 26: TEM of macrophage (group I) with irregularity of the outline and an oval large nucleus (N). Multiple lysosomal bodies (Lb), rough ER (rER), well developed Golgi apparatus (G) and mitochondria (m) are seen in the cytoplasm. TEM, X7200.

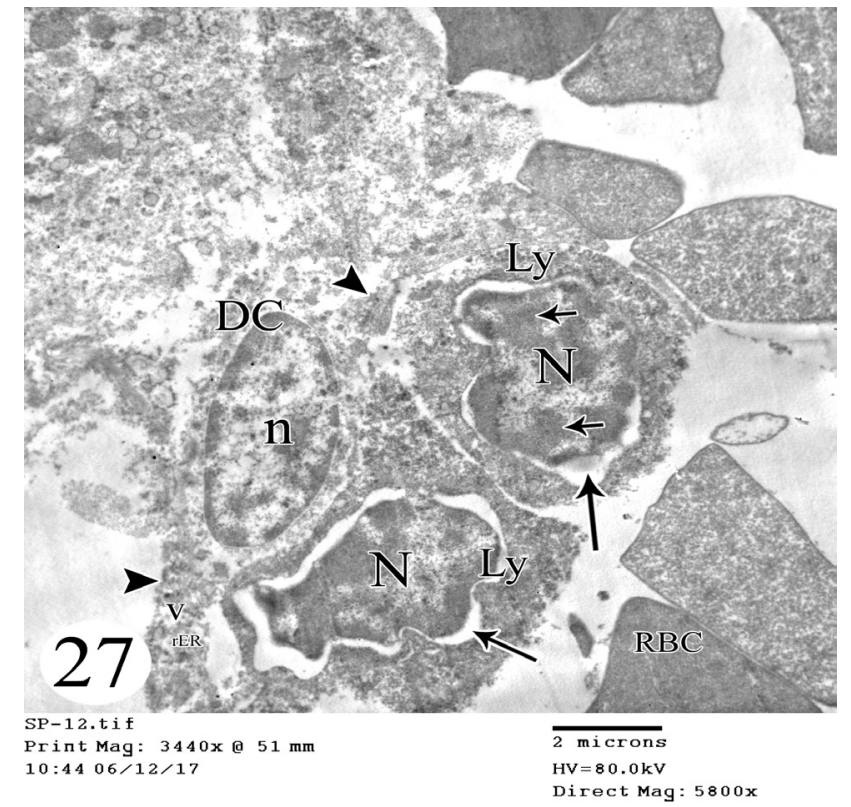

Fig. 27: TEM of lymphocytes (Ly) (group II) with dark nuclei $(\mathrm{N})$ which reveal peripheral chromatin margination and many coarse heterochromatin clumps (short arrows). Dilated perinuclear cisternae (arrows) are observed. Their cytoplasm shows increased density with hardly identified organelles. Note a DC with some cytoplasmic processes (arrow heads) and ill defined cell boundaries. The cell contains a heterochromatic nucleus (n) with cytoplasmic vacuolations (V) and dilated rough ER (rER). RBCs are observed. TEM, X 5800.

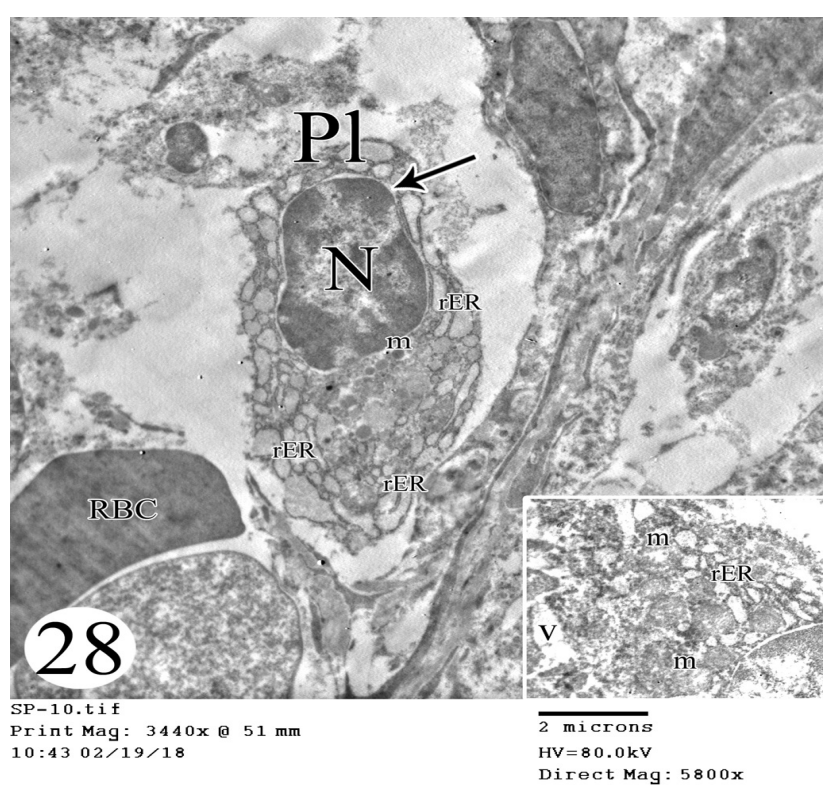

Fig. 28: TEM of plasma cell (Pl) (group II) showing eccentric nucleus (N) with increase heterochromatin and dilated cisternae around the nucleus (arrow). The cytoplasm shows electron dense mitochondria $(\mathrm{m})$ and markedly dilated rough ER (rER). Note RBCs. Inset: Apart of plasma cell showing markedly dilated rough ER (rER), vacuolations (V) and swollen mitochondria with distorted cristae (m). TEM, X5800. 


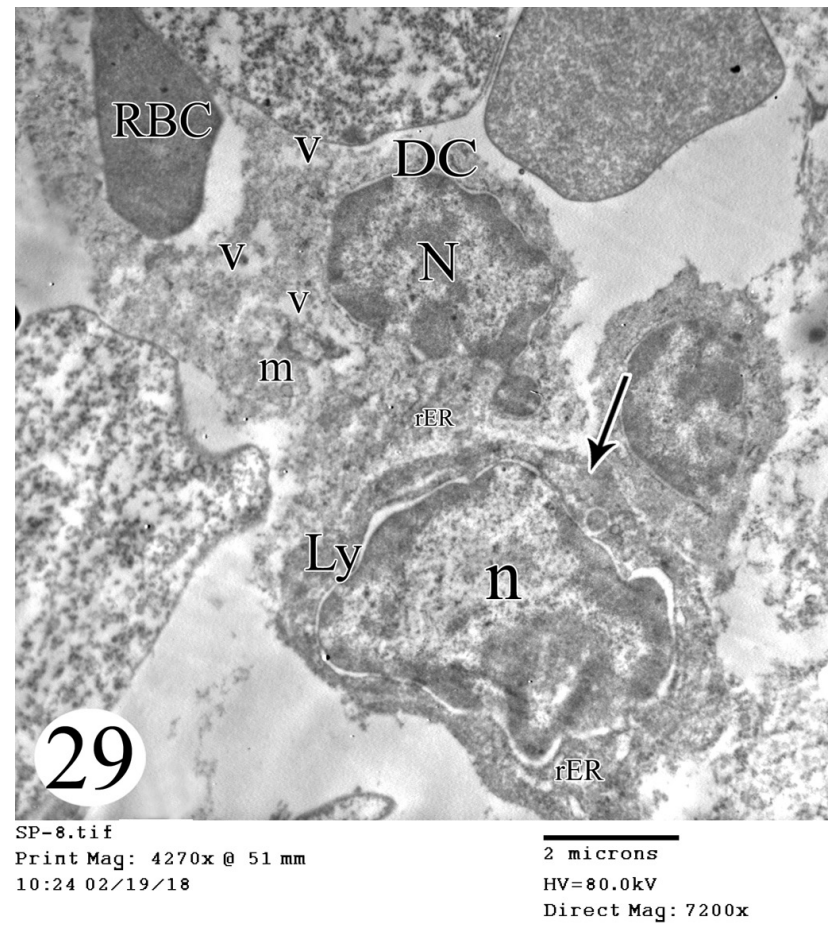

Fig. 29: TEM of a DC (group II) showing increase heterochromatin inside the nucleus $(\mathrm{N})$ and vacuolated rarified cytoplasm $(\mathrm{V})$ containing vacuolated mitochondria $(\mathrm{m})$ and dilated rough ER (rER). Note a lymphocyte (Ly) with a dark nucleus (n) and dark cytoplasm (arrow) revealing dilated rough ER (rER). RBCs can be observed. TEM, X7200.

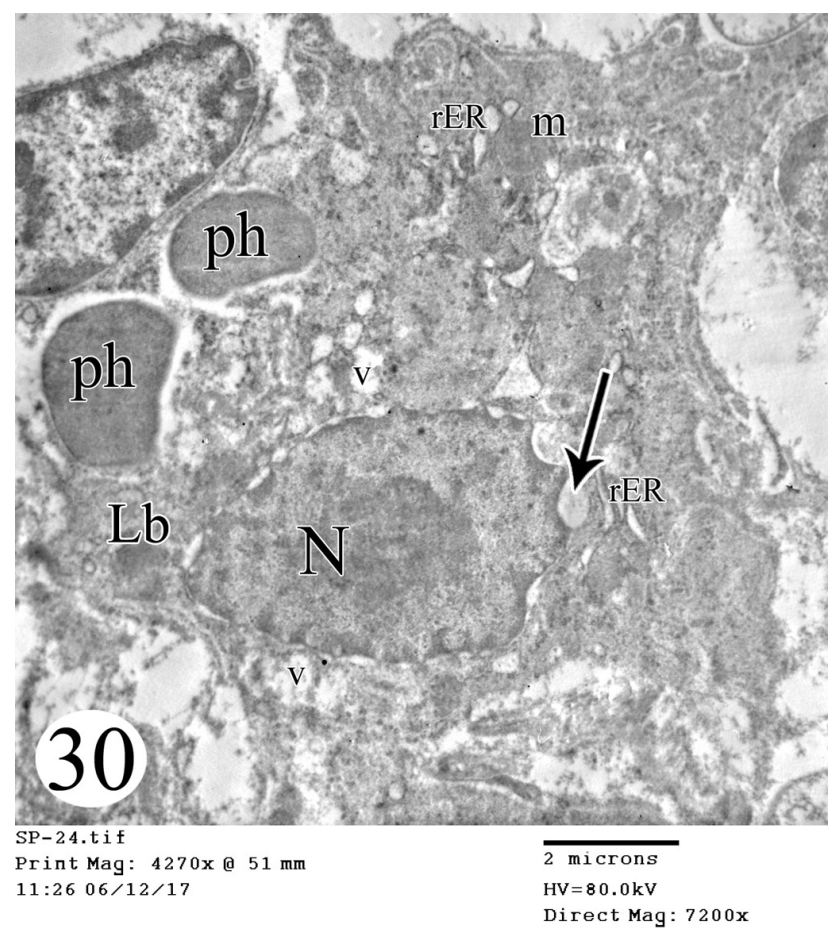

Fig. 30: TEM of macrophage (group II) containing a large electron dense eccentric nucleus $(\mathrm{N})$ revealing irregular nuclear envelope with dilated cisternae (arrow). The cytoplasm shows multiple phagosomes (ph), lysosomal bodies $(\mathrm{Lb})$ with heterogenous contents, markedly dilated rough ER (rER), swollen electron dense mitochondria $(\mathrm{m})$ and numerous vacuoles (V). TEM, X7200

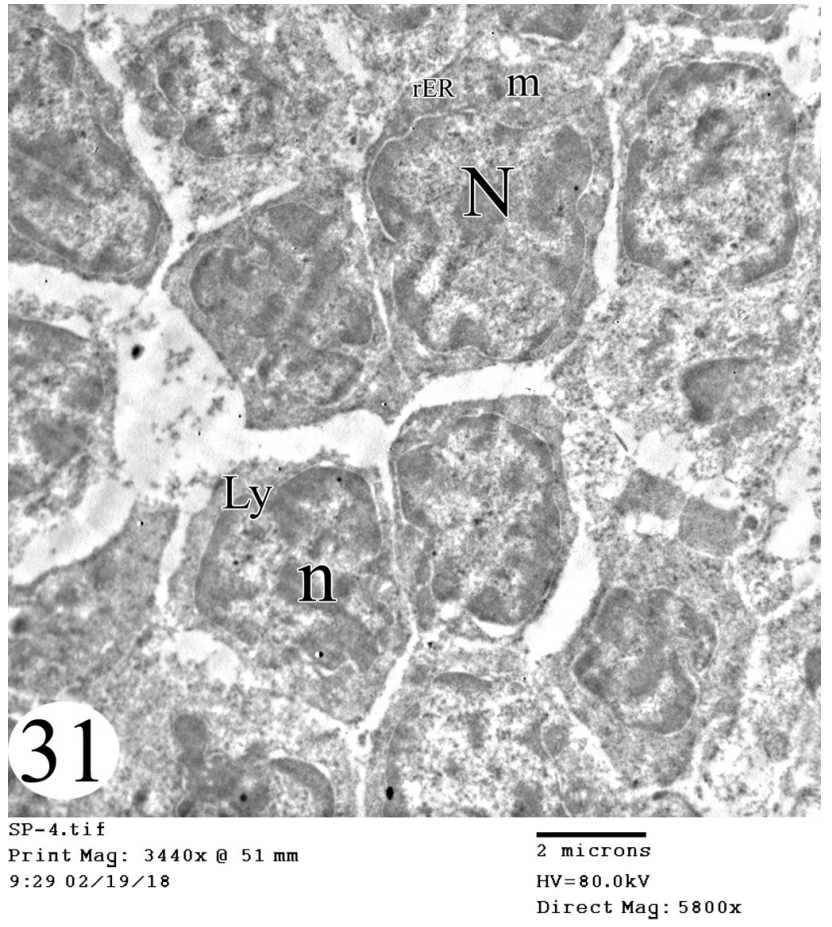

Fig. 31: TEM of lymphocytes (group III). Small lymphocyte (Ly) appears with condensed nuclear chromatin and a thin rim of cytoplasm which surrounds the nucleus (n). Large lymphocyte has euchromatic nucleus (N) and the cytoplasm contains small mitochondria (m) and rough ER (rER). TEM, X5800.

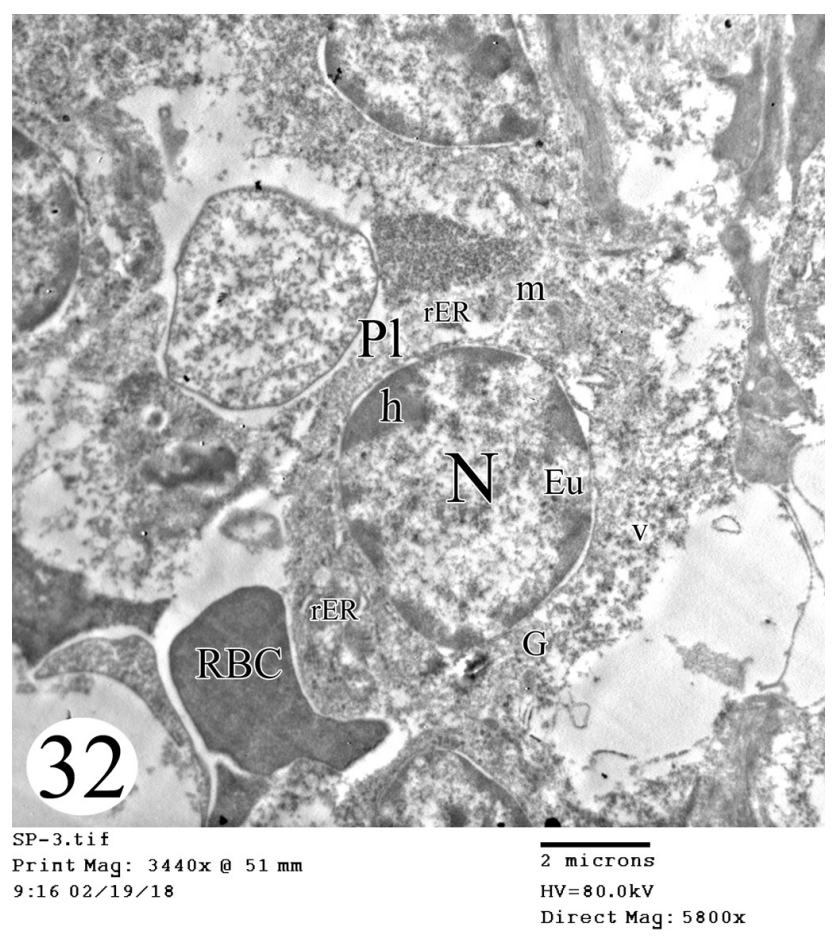

Fig. 32: TEM of plasma cell (Pl) (group III) with a large eccentric nucleus containing coarse heterochromatin (h) alternating with euchromatin $(\mathrm{Eu})$ with few dilated rough ER cisternae (rER), Golgi complex $(\mathrm{G})$ and mitochondria $(\mathrm{m})$. Vacuolated areas $(\mathrm{V})$ and RBCs can be noticed. TEM, X5800. 


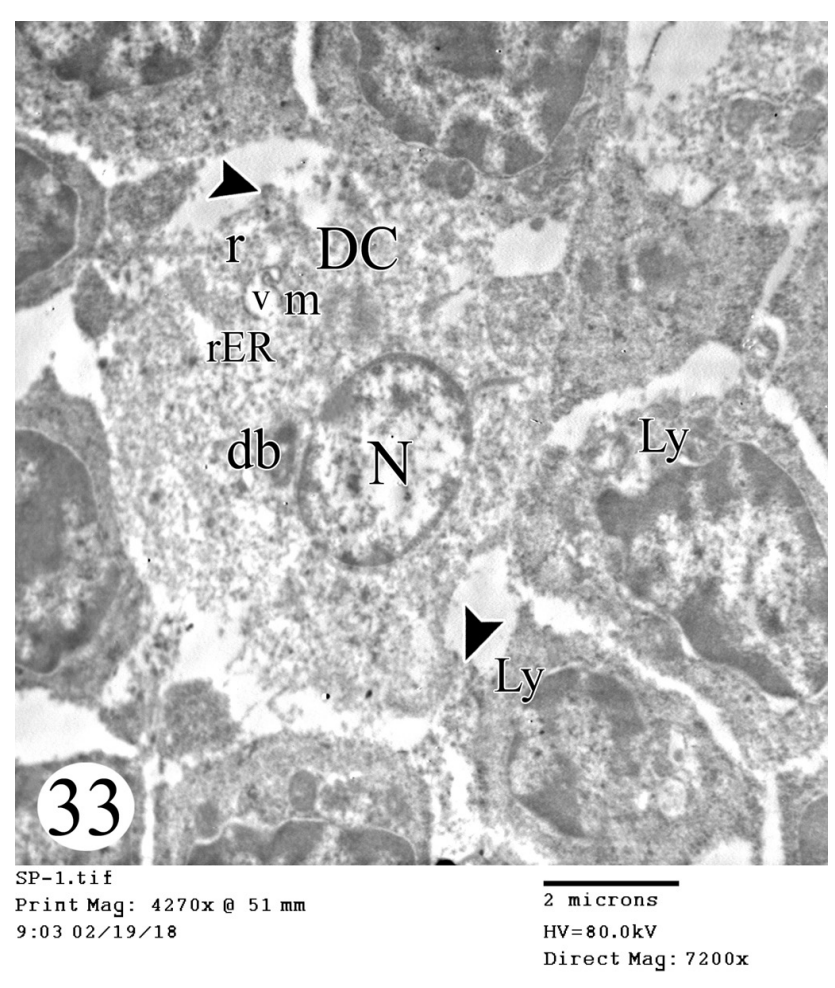

Fig. 33: TEM of a dendritic cell (DC) (group III) with an eccentric nucleus (N) and many cytoplasmic processes (arrow heads) in contact with lymphocytes (Ly). Its cytoplasm reveals mitochondria (m), slightly dilated rough ER (rER), dense bodies (db) and abundant ribosomes (r). Minute vacuoles are noticed (V). TEM, X7200.

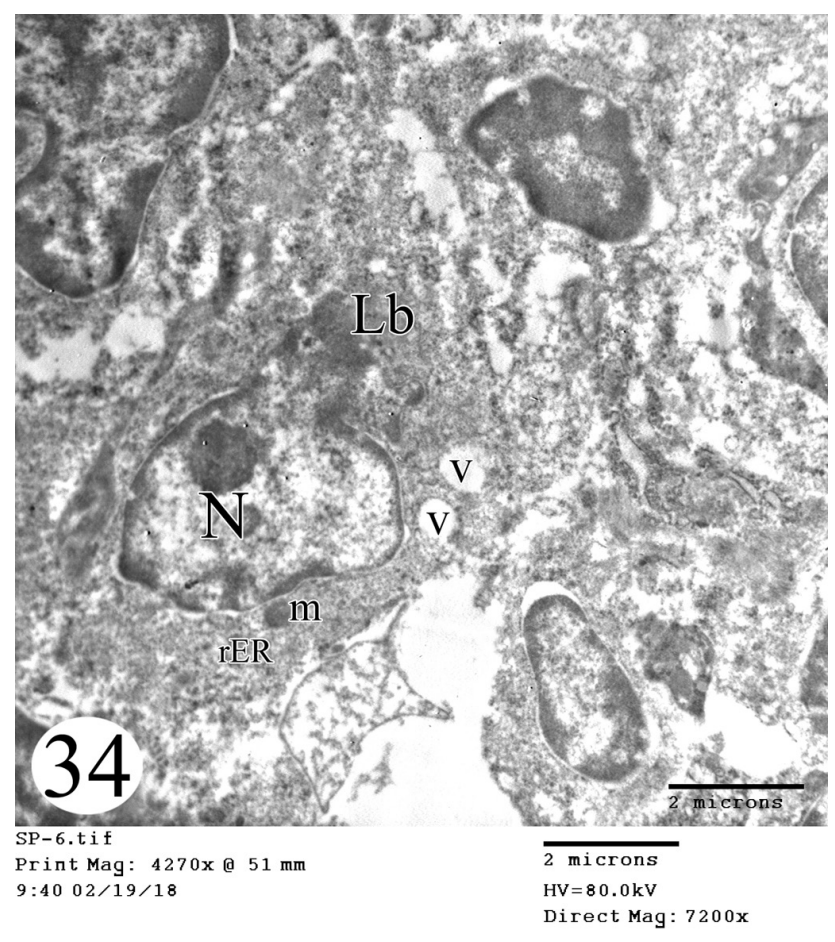

Fig. 34: TEM of macrophage (group III) with an irregular outline and eccentric nucleus $(\mathrm{N})$. Multiple lysosomal bodies with heterogenous contents (Lb), mitochondria (m), rough ER (rER) and some vacuolations (V) are noticed in the cytoplasm. TEM, X7200.

\section{DISCUSSION}

Obesity is a hyperlipidemia state which is considered abnormal[ ${ }^{[29]}$. It is related with main causes of mortality and morbidity such as liver and spleen diseases and diabetes ${ }^{[30]}$.

Vitamin D3 is vitamin D form which posseses the most potent effect on immune response regulation ${ }^{[31]}$. Changes to DCs are central to vitamin D power to modulate immune responses $^{[32]}$.

High-fat diet group (group II) in this work revealed marked histological alterations. Most of white pulp cells had degenerative changes like pale vacuolated cytoplasm, dense nuclei and empty wide spaces. The red pulp revealed disturbed architecture with some degenerated cells. Deposition of hemosidrin pigments in the cytoplasm of many cells, markedly dilated blood sinusoids and blood extravasation were seen. Similar findings were observed in rats' spleen with HFD in other previous studies ${ }^{[33]}$. In accordance with the current results, some authors ${ }^{[34]}$ found that with high fat diet, splenic sections revealed degeneration, deposition of hemosiderin and dilatation of blood sinusoids. They suggested that obesity can cause splenomegaly via hemosiderin deposition and splenic sinus dilatation. They added that hemorrhagic lesions and congestion represented the disorganized and depleted lymphoid system. Some investigators ${ }^{[35]}$ explained this dilatation by hypoxia and ischemia occurring after HFD. Another explanation by some authors ${ }^{[36]}$ who reported that the developing hypertension as a result of obesity induced by HFD may cause vascular dilatation.

In the present work, lymphatic follicles proliferation was observed which might indicate immunity activation in the spleen of HFD fed animals. The current finding was augmented by some authors ${ }^{[15]}$ who reported that in obesity, the immune splenic dysfunction which was detcted as an increase in the immune system activity suggested that splenic immune responses are involved in the pathophysiology of obesity. On the other side, many studies showed that obesity induced by HFD can decrease the antioxidant activity in different organs ${ }^{[37]}$.

Lumeng and Saltiel ${ }^{[38]}$ reported the connection of obesity with a chronic, proinflammatory condition. This inflammation has been incorporated in the elevation of levels of inflammatory mediators ${ }^{[13]}$. This inflammation was attributed to the increased macrophages infiltration and/or the rise in genes expression which are involved with adipose tissue inflammation ${ }^{[39]}$. Moreover, over feeding can cause inflammatory response stimulation through an anti-inflammatory path-ways down regulation such as that of IL-10, as B-cells which produce IL-10, mainly in the spleen were decreased by consumption of HFD ${ }^{[40]}$.

Apoptosis is a form of regulated cell death in tissues initiated by the activation of cysteine proteases of the caspase family including caspase-3. On activation, caspase- 3 which is an index of apoptosis cleaves different proteins related to the structural integrity of the cell[ ${ }^{[41]}$. Splenic sections immunostained with caspase-3 in group II of the current study showed caspase-3 intense immune reaction. In line with the present finding, some 
investigators $^{[42]}$ detected that HFD caused increase in apoptotic cells in the spleen. High caspase-3 expression might be interpreted by its involvement in both immune and inflammatory reactions to dying cells ${ }^{[41]}$. Apoptosis in the spleen has been found to result in disturbances in the immune system ${ }^{[43]}$.

CD86 tissue distribution has been well established in the mouse and human and is clearly expressed by DC, in all species $^{[22,23,12]}$. Moreover, disturbed immune function with impaired DC functioning as a consequence of inflammation associated with obesity was documented ${ }^{[44]}$. In this work, there was a prominent CD86 (DC-antibody) expression in DC-cytoplasm of rats' spleen with HFD. The increase in CD86 expression in this work suggested that the state of inflammation which was recorded resulted in stimulation of DC maturation. The present results were augmented by other authors ${ }^{[45]}$ who claimed that under the steady noninflammatory state, DCs are present as immature cells with low expression of surface CD86, while on becoming mature, there is high CD86 expression in these cells. For the acquired immune response to be initiated it requires maturation of DC.

Nitric oxide is a physiological regulator of diverse functions in several tissues and iNOS is a major component of oxidative stress and inflammation ${ }^{[29]}$. In this work, immunostained splenic sections in group II showed a strong positive cytoplasmic immunoreactivity to iNOS. The current results were supported by some investigators ${ }^{[46]}$ who reported that high fat diet induced NO activities observed in different tissues of rats which reflected inflammation increase. Aydin ${ }^{[29]}$ also declared that NO production in all organ tissues was affected by HFD. They added that HFD induced obesity promoted systemic oxidative stress as evidenced by decreased glutathione and antioxidant enzymes. So, in obesity there is a close association between obesity and oxidative stress.

Ultrathin sections of group II in this work showed maked ultrastructural affection of different splenic cells including lymphocytes, plasma cells, DCs and macrophages. The fine structural changes occurred were in the form of ill defined plasma membrane, nuclei with chromatin margination and electron dense nuclei with perinuclear cisternae dilatation. Their cytoplasm revealed numerous vacuoles, marked dilatation of rough ER and swollen mitochondria with distorted cristae. In line with these results, Altunkaynak and Ozbek ${ }^{[47]}$ detected similar findings in the hepatocytes of HFD fed animals.

In harmony with the present findings, Rabinowitz and White ${ }^{[48]}$ supposed that the increase in oxidative stress and mitochondrial dysfunction with HFD might be associated with degradation of protein, ER stress, apoptosis and autophagy. Dysfunction of mitochondria and ER stress are essential for $\beta$-cell dysfunction ${ }^{[49]}$.

Dendritic cells are antigen presenting cells (APCs) that found in both lymphoid and non-lymphoid tissues as complex networks which play a pivotal role in adaptive and innate immunity linking and regulation ${ }^{[50]}$. The insult detected in DCs as a result of HFD in the current study was interpreted by some investigators ${ }^{[51]}$ who proposed that demonstration of a functional deficiency of DCs and an alteration of their steady-state number could give partial explanation of the immune deficiency which is commonly associated with the obese state.

The present results revealed multiple phagosomes and lysosomal bodies with heterogenous contents in macrophage cell cytoplasm in group II. In harmony with the present results, some studies stated that macrophages acquire lipid droplets in their cytoplasm once they ingest and process lipid ${ }^{[52]}$.

Vitamin D treatment in association with HFD in this study showed dramatic preservation of the histological and immunohistochemical picture of the spleen with nearly normal appearance. In line with the results of this study, other animal studies ${ }^{[53]}$ have shown that vitamin D supplementation protects against HFD-induced metabolic parameters. In harmony, Larsson and Voss ${ }^{[19]}$ suggested that supplementation of vitamin $\mathrm{D}$ in the diet could protect enteric neurons against obesity-induced damage. The present results were augmented by other authors ${ }^{[44]}$ who reported that vitamin D through peroxidation stress lowering can reduce tissue damage. The anti-oxidant effects of vitamin D could be explained by its ability to increase the key anti-oxidative enzymes levels such as glutathione (GSH), superoxide dismutase (SOD) and catalase $^{[55]}$. Eugene and Yangha ${ }^{[56]}$ stated that in adipocytes, vitamin $\mathrm{D}$ is incorporated in the regulation of lipogenesis, differentiation, apoptosis, as well as acting as an antiinflammatory agent.

Jones $^{[57]}$ declared that vitamin $\mathrm{D}$ is considered as an essential modulator in inflammation, cellular differentiation, proliferation and immune systems. The main vitamin D immunomodulatory and anti-inflammatory properties were via pro-inflammatory cytokine production inhibition and anti-inflammatory cytokines expression enhancement by direct action on APCs or T lymphocytes ${ }^{[58]}$. Evidence for the anti-inflammatory effect of vitamin $\mathrm{D}$ administration was confirmed by previous studies ${ }^{[59]}$ which reported a significant increase in IL-10 serum level on administration of vitamin D in the HFD-fed animals. The beneficial anti-inflammatory action of IL-10 was attributed to its ability to block activation of monocytes and to attenuate inflammatory mediators production ${ }^{[60]}$. Other authors ${ }^{[61]}$ attributed the anti-inflammatory effects of vitamin D to its power in reduction of the HFD-induced increases in tumor TNF $\alpha$ and pro-inflammatory cytokines such as IL-6 and lipid peroxidation products

In this work, there was weak caspase- 3 immunoreactivity in group III. The present findings were in harmony with the results of other researchers ${ }^{[62]}$ who declared that vitamin $\mathrm{D}$ protects rat's heart from the activated cardiac extrinsic pathways of apoptosis as a consequence of feeding with HFD. The current results were supported by some 
investigators ${ }^{[63]}$ who claimed that administration of vitamin D can cause caspase- 3 expression decrease in the spleen resulting in inhibition of the caspase-dependent pathway of apoptosis. The anti-apoptotic effect of vitamin D could be caused by its ability to enhance IL-10 expression which is capable of supporting cell survival through the block of cytochrome $\mathrm{C}$ release and caspase cleavage with the resultant reduction in caspase-3 activation.

In this work, there was a decrease in the reaction intensity of CD86 in DC cytoplasm which is nearly like control. In line with the current results, some researchers ${ }^{[64]}$ declared that treatment of DCs with vitamin D leads to low surface expression of costimulatory molecules, such as CD86 and enhanced IL-10 secretion resulting in T-cell hyporesponsiveness. In accordance, other investigators ${ }^{[65]}$ declared improvement in the inflammatory and immune responses by vitamin $\mathrm{D}$ via decrease in the expression of CD86. Some authors ${ }^{[66]}$ added that the receptors for vitamin $\mathrm{D}$ are expressed in the immune cells; this could explain the immunomodulatory effects of vitamin D and might clarify the association between vitamin D and a large number of autoimmune and inflammatory diseases.

According to the previous studies and this current study, it was concluded that the mechanism by which vitamin D could lower CD86 expression was most probably explained by its power to increase serum level of IL-10 which resulted in downregulation of CD86 resulting in the immunomodulatory and anti-inflammatory effects of vitamin D.

The weak iNOS immunoreactivity detected in group III of this study was in agreement with some investigators ${ }^{[67,68]}$ who postulated that vitamin D regulates iNOS, a marker of oxidative damage and reported low levels of iNOS expression, which is an indicator of oxidative stress related cell death. They added that treatment with vitamin D induced low levels of iNOS expression in many neurons. They concluded that vitamin D has the ability to prevent oxidative damage by suppressing iNOS expression.

From the current study, it was concluded that HFD induced deleterious effects on the splenic structure which can lead to splenic and immune system dysfunction. Coadministration of vitamin-D had a protective role and attenuated these hazardous effects. The preventive vitamin D role might be attributed to its antioxidant, anti-apoptotic, immunomodulatory and anti-inflammatory effects.

\section{CONFLICT OF INTEREST}

There are no conflicts of interest.

\section{REFRENCES}

1. Chan RS, Woo J. Prevention of Overweight and Obesity: How Effective is the Current Public Health Approach. International Journal of Environmental Research and Public Health. 2010; 7(3), 765-783.
2. Trayhurn P, Wood IS. Adipokines: inflammation and the pleiotropic role of white adipose tissue. Br J Nutr. 2004; 92:347-355.

3. Brantley PJ, Myers VH, Roy HJ, Environmental and lifestyle influences onobesity. J. La. State Med. Soc. 2005; 157: 19-27, Spec No 1.

4. Buettner R, Scholmerich J and Bollheimer LC Highfat diets: modeling the metabolic disorders of human obesity in rodents. Obesity. 2007; 15: 798-808.

5. Wang X, Cheng M, Zhao M, Ge A, Guo F, Zhang $\mathrm{M}$ et al. Differential effects of high-fat-diet rich in lard oil or soybean oil onosteopontin expression and inflammation of adipose tissue in diet-inducedobese rats. Eur. J. Nutr. 2013; 52: 1181-1189.

6. Andruszkow H, Veh J, Mommsen P, Zeckey C, Hildebrand F, Frink M. Impact of the body mass on complications and outcome in multiple trauma patients: what does the weight weigh? Mediators of Inflammation. 2013; 1-8.

7. Ramos EJ, Xu Y, Romanova I. Is obesity an inflamatuar disease? Surgery 2003; 134 (2):329-35.

8. Ciesla DJ, Moore EE, Johnson JL, Burch JM, Cothren CC, Sauaia A, Obesity increases risk of organ failure after severe trauma. Journal of the American College of Surgeons. 2006; 203: 39-45.

9. Kaminski DA, Randall TD. Adaptive immunity and adipose tissue biology. Trends Immunol. 2010; 31:384-390.

10. Noeman SA. Hamooda HE. Biochemical study of oxidative stress markers in the liver, kidney and heart of high fat diet induced obesity in rats. Diabetology and Metabolic Syndrome. 2011; 3: 1-17.

11. Bryan S, Baregzay B, Spicer D, Singal PK, Khaper $\mathrm{N}$, Redox-inflammatory synergy in the metabolic syndrome. Canadian Journal of Physiology and Pharmacology. 2013; 91: 22-30.

12. Zhao F, Pang W, Zhang Z, Zhao J, Wang X, Liu Y et al. Pomegranate extract and exercise provide additive benefits onimprovement of immune function by inhibiting inflammation and oxidative estress in high-fat-diet-induced obesity in rats. J. Nutr. Biochem. 2016; 32:20-28.

13. Wilson RM, Messaoudi I. The impact of maternal obesity during pregnancyon offspring immunity. Mol. Cell. Endocrinol. 2015; 418 (Part 2):134-142.

14. Lamas O, Martínez JA, Marti A. Decreased splenic mRNA expression levels of TNF-alpha and IL-6 in diet-induced obese animals. J Physiol Biochem 2004;;60:279-283.

15. Leite Nd.C, Montes EG, Fisher SV, Cancian CRC, de Oliveira JC,.Martins-Pinge MC et al. Splenectomy attenuates obesity and decreases insulin hypersecretion in hypothalamicobese rats, Metabolism. 2015; 64:1122-1133. 
16. Kearns MD, Alvarez JA, Seidel N, Tangpricha V. Impact of Vitamin D oninfectious disease. Am. J. Med. Sci. 2015; 349:245-262.

17. Zittermann A, et al. Vitamin D supplementation enhances the beneficial effects of weight loss on cardiovascular disease risk markers. Am J Clin Nutr. 2009;89(5):1321-1327.

18. Salehpour A, Hosseinpanah F, Shidfar F, Vafa M, Razaghi M, Dehghani S et al. A 12-week doubleblind randomized clinical trial of vitamin $\mathrm{D}(3)$ supplementation on body fat mass in healthy overweight and obese women. Nutr J. 2012;11:78.

19. Larsson S, Voss U. Neuroprotective effects of vitamin $\mathrm{D}$ on high fat diet- and palmitic acid-induced enteric neuronal loss in mice. BMC Gastroenterology. 2018; 18(1):175.

20. S.O.L.A.N, National research council, committe on animals nutrition, board onagriculture, nutrient requirements of the laboratory rat, in: NutrientRequirements of Laboratory Animals, revised edition, National Academy press, Washington, D.C, 1995, p. 11-79.

21. Burgmaier M, Sen S, Philip F. Metabolic adaptation follows contractile dysfunction in the heart of obese Zucker rats fed a high-fat "Western" diet. Obesity (Silver Spring, Md.). 2010; 18(10):1895-1901.

22. Zaman MQ, Leray V, Le Bloc'h J, Thorin C, Ouguerram K, Nguyen P. Lipidp rofile and insulin sensitivity in rats fed with high-fat or high-fructose diets. Br. J. Nutr. 2011; 106(1):206-210.

23. Yin Y, Yu Z, Xia M, Luo X, Lu X, Ling W. Vitamin $\mathrm{D}$ attenuates high fat diet-induced hepatic steatosis in rats by modulating lipid metabolism. Eur. J.Clin. Invest. 2012; 42:1189-1196.

24. Bancroft JD, Gamble M. Theory and practice of histological techniques. 6th ed. Edinburgh, London, New York, Tokyo: Churchill Livingstone; 2008. p. 121.

25. Graham L, Orenstein JM. Processing tissue and cells for transmission electron microscopy in diagnostic pathology and research. Nature protocols. 2007; 2(10):2439-50.

26. Aktuğ H, Kosova B, Yavasoğlu A., Cetintas VB. Evaluation of caspase- 3 and bcl-2 expressions in spleen tissue of streptozotocin-induced diabetic rats byimmunohistochemistry and quantitative RT-PCR. Ege J. Med. 2010; 49:1-6.

27. Damoiseaux JG, Yagita H., Okumura K, Vriesman PJ. Costimulatory molecules CD80 and CD86 in the rat; tissue distribution and expression by antigenpresenting cells. Journal of Leukocyte Biology. 1998; 64(6):803-809.
28. Kiernan JA. Histological and histochemical methods: theory and practice. $3^{\text {rd }}$ ed. Oxford: A Hodder Arnold Publication; 2001.

29. Aydin B. The Effects of Capsaicin and Vitamine E on High Fat Diet Induced Obesity, Hyperlipidemia and Oxidative Stress in Different Organs of Mice. Journal of Food and Nutrition Research. 2015; 3 (6,):357-364.

30. Kortt MA, Clarke PM. Estimating Utility Values for Health States of Overweight and Obese Individuals Using the SF-36. Qual Life Res. 2005; 14: 2177-2185.

31. Bang UC, Brandt L, Benfield T, Jensen JEB. "Changes in 1,25-dihydroxyvitamin D and 25-hydroxyvitamin $\mathrm{D}$ are associated with maturation of regulatory $\mathrm{T}$ lymphocytes in patients with chronic pancreatitis: a randomized controlled trial." Pancreas. 2012; 41(8):1213-1218.

32. Gorman S, Judge MA, Hart PH. "Immune-modifying properties of topical vitamin D: focus on dendritic cells and T cells."The Journal of Steroid Biochemistry and Molecular Biology. 2010. 121(1-2):247-249.

33. Suttie AW. Histopathology of the spleen. Toxicol Pathol. 2006; 34:466-503.

34. Altunkaynak B.Z, Ozbek E, Altunkaynak ME. A stereological and histologicalanalysis of spleen on obese female rats, fed with high fat diet. Saudi Med. J. 2007; 28:353-357.

35. Arvanitidis AP, Corbett D, Colbourne F. A high fat diet does not exacerbate CA1 injury and cognitive deficits following global ischemia in rats. Brain Res. 2009; 1252: 192- 200.

36. Duda MK, O'Shea KM, Lei B, Barrows BR, Azimzadeh AM, McElfresh TE et al. Low-carbohydrate/highfat diet attenuates pressure overload-induced ventricular remodeling and dysfunction. J Card Fail. 2008; 14: 327-35.

37. Wang, S., Kaufman, R.J., The impact of the unfolded protein response on human disease. Journal of Cell Biology, 2012; 197:857-867.

38. Lumeng CN, Saltiel AR. Inflammatory links between obesity and metabolic disease. J Clin Invest. 2011; 121:2111-2117.

39. Suganami T, Nishida J, Ogawa Y. A paracrine loop between adipocytes andmacrophages aggravates inflammatory changes: role of free fatty acids andtumor necrosis factor alpha, Arterioscler. Thromb. Vasc. Biol. 2005; 25:2062-2068.

40. Spoto B., Zoccali C. Spleen IL-10, a key player in obesity-driven renal risk,Nephrol. Dial. Transplant. 2013; 28: 1061-1064.

41. Galluzzi L, López-Soto A, Kumar S, Kroemer G. Caspases connect cell-deathsignaling to organismal homeostasis. Immunity. 2016; 44:221-231. 
42. Cui J, Xiao Y, Shi YH, Wang, Le GW. Lipoic acid attenuateshigh-fat-diet-induced oxidative stress and B-cell-related immune depression,Nutrition 2012; 28:275-280.

43. Gu W, Zhang Q, Yin W, Li C, Caspase-3-mediated splenic lymphocyteapoptosis in a porcine model of cardiac arrest. Am. J. Emergency Med. 2014; 32:1027-1032.

44. Karlsson EA, Beck M.A. The burden of obesity on infectious disease, Exp. Biol.Med. 2010; 235: 1412-1424.

45. Sumpter TL, Abe M, Tokita D, Thomson AW. Dendritic cells, the liver, andtransplantation. Hepatology. 2007; 46: 2021-2031.

46. Ou Y, Liu R, Wei N, Li X, Qiang O, Huang W et al. Effects of octreotide on nitric oxide synthase expression in the small intestine of high fat dietinduced obese rats. Obesity Research and Clinical Practice. 2012; 6(4):263-346.

47. Altunkaynak BZ, Ozbek E. Overweight and structural alterations of the liver in female rats fed a high-fat diet: A stereological and histological study. Turk J Gastroenterol. 2009; 20 (2): 93-103.

48. Rabinowitz JD, White E. Autophagy and metabolism. Science. 2010; 330: 1344- 1348.

49. Leemand J, Koh EH. Interaction between Mitochondria and the Endoplasmic Reticulum: Implications for the Pathogenesis of Type 2 DiabetesMellitus. Experimental Diabetes Research. 2012; Volume 2012, pages 1-8.

50. Kingston D, Schmid MA, Onai N, Obata-Onai A, Baumjohann D, Manz MG. The concerted action of gm-csf and flt3-ligand on in vivo dendritic cell homeostasis. Blood. 2009; 114:835- 843.

51. Macia L, Delacre M, Abboud G, Ouk TS, Delanoye A, Verwaerde $\mathrm{C}$ et al. Impairment of Dendritic Cell Functionalityand Steady-State Number in Obese Mice. J Immunol. 2006; 177:5997-6006.

52. Subramanian M, Thorp E, Hansson GK, Tabas I. Treg-mediated suppression of atherosclerosis requires myd88 signaling in dcs. J Clin Invest. 2013; 123 : $179-188$

53. Marcotorchino J, Tourniaire F, Astier J, Karkeni E, Canault M, Amiot MJ et al. Vitamin D protects against diet-induced obesity by enhancing fatty acid oxidation. J Nutr Biochem. 2014;25(10):1077-1083.

54. Ke CY, Yang FL, Wu WT, Chung CH., Lee RP, Yang WT et al. Vitamin D3 Reduces Tissue Damage and Oxidative Stress Caused by Exhaustive Exercise. International Journal of Medical Sciences. 2016; 13(2): 147-153.
55. Farhangi MA, Nameni G, Hajiluian G, MesgariAbbasi M. Cardiac tissue oxidative stress and inflammation after vitamin D administrations in high fat- diet induced obese rats. BMC Cardiovasc Disord. 2017; 17(1):161.

56. Eugene C, Yangha K. Vitamin D Decreases Adipocyte Lipid Storage and increases NAD-SIRT1 Pathway in 3T3-L1 Adipocytes. Nutrition. 2016; 32(6):702-708.

57. Jones G. Expanding role for vitamin D in chronic kidney disease: importance of blood 25-OH-D levels and extra-renal 1alpha-hydroxylase in the classical and nonclassical actions of 1alpha,25-dihydroxyvitamin D(3). Semin. Dial. 2007; 20:316-324.

58. Boonstra A, Barrat FJ., Crain C, Heath VL., Savelkoul HF, O'Garra A. 1alpha,25-Dihydroxyvitamin d3 has a direct effect on naive CD4(+) T cells to enhance the development of Th2 cells. J. Immunol. (Baltimore, Md. 1950). 2001.; 167:4974-4980.

59. de Medeiros Cavalcante IG, Silva AS, Costa MJ, Persuhn DC, Issa CT, de Luna Freire TL et al. Effect of vitamin D3 supplementation and influence of BsmI polymorphism of the VDR gene of the inflammatory profile and oxidative stress in elderly women with vitamin D insufficiency: Vitamin D3 megadose reduces inflammatory markers. Exp Gerontol. 2015; 66: 10-6.

60. Mu W., Ouyang X., Agarwal A., Zhang L., Long D.A., Cruz P.E. et al. IL-10 suppresses chemokines, inflammation, and fibrosis in a model of chronic renal disease, J. Am. Soc. Nephrol. 2005; 16: 3651-3660.

61. Kheder R, Hobkirk J, Saeed Z, Janus J, Carroll S, Browning MJ, Stover C. Vitamin D3 supplementation of a high fat high sugar diet ameliorates prediabetic phenotype in female LDLR(-/-) and LDLR(+/+) mice. Immun Inflamm Dis. 2017; 5(2): 151-162.

62. Al-Solami KM, Al-refaie Z, Awad H, Rasool M. Potential Protective Effect of Vitamin D on Cardiac Extrinsic pathways of apoptosis in Male Rats Fed with high fat diet. Genetics and Molecular Research. 2019; 18 (1): 2-7.

63. Zhou Z, Peng X, Insolera R, Fink DJ, Mata M. IL10 promotes neuronalsurvival following spinal cord injury. Exp. Neurol. 2009; 220:183-190.

64. Takeda M., Yamashita T., Sasaki N., Nakajima K., Kita T., Shinohara M. et al. Oral Administration of an Active Form of Vitamin D3 (Calcitriol) Decreases Atherosclerosis in Mice by Inducing Regulatory $\mathrm{T}$ Cells and Immature Dendritic Cells With Tolerogenic Functions. Arterioscler Thromb Vasc Biol. 2010; 30: 2495-2503. 
65. Bartels LE, Jorgensen SP, Bendix M, Hvas CL, Agnholt J, Agger R et al. 25-Hydroxy vitamin D3 modulates dendritic cell phenotype andfunction in Crohn's disease. Inflammopharmacology. 2013; 21:177-186

66. Guillot X, Semerano L, Saidenberg-Kermanac'h N, Falgarone G, Boissier MC. Vitamin D and inflammation. Joint Bone Spine. 2010; 77: 552-557.
67. Dursun E, Gezen-Ak D, Yilmazer SA. New Mechanism for Amylo-id-BInduction of iNOS: Vitamin D-VDR Pathway Disruption. J Alzhe $\neg$ imers Dis. 2013; 36(3):459-474.

68. Dursun E, Gezen-Ak D, Yilmazer S. The Influence of Vitamin D Treatment on the Inducible Nitric Oxide Synthase (INOS) Expression in Primary Hippocampal Neurons Vitamin D. Archives of Neuropsychiatry. 2014; 51(2): 163-168. 


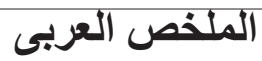

\title{
تأثير فيتامين د على الطحال فى ذكور الجرذان البالغة التى تغذت على نظام غذائى عالى الدهون: دراسة هستولوجية ولونية وهنتوكيميائية مناعية
}

\author{
هبة كمال محمد \\ قسم التشريح الادمى وعلم الأجنة ـ كلية الطب - جامعة أسيوط
}

المقدمة: إن النظام الغذائي العالي الدهون مسئول عن ارتفاع معدل انتشار للبدانة والتى تعد مشكلة صحية خطيرة. ويعتبر فيتامين-د مغير هام فى الإلثهابات الخلوية وأجهزة المناعة. الهدف من البحث: الهدف من هذه الدراسة هو توضيح التغيرات الهستولوجية فى طحال ذكور الجرذان البالغة التى هئ تغذت على نظام غذائى عالى الدهون وتقييم دور فيتامين-د في مقاومة الثأثنير ات الضارة للنظام الغذائى عالى الدهون على الطحال. المواد وطرق البحث: تم تقسيم ستة وثلاثين من ذكور الجرذان البالغة عشو ائيا بالتساوي إلى ثلاث مجمو عات: المجمو عة الضابطة التى تلقت النظام الغذائى المعتاد لمدة عثرة أسابيع، المجموعة التى تلقت نظام غذائى عالى الدهون لمدة عثرة

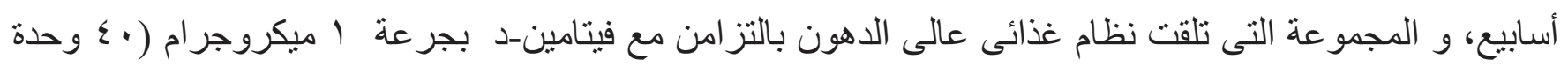
دولية) لمدة عشرة أسابيع. تم اخذ عينات من الطحال وتم تجهيز ها للار اسة الهستولوجية و الهستوكيمبائية مناعية. النتائج: أظهرت المجموعة التى تلقت النظام الغذائى عالى الدهون تغيرات نسيجية ملحوظة مع تكاثر فى البصيلات اليمفاوية فى لب الطحال الأبيض.كما ظهرت علامات التحلل فى معظم خلايا الطحال. كما لوحظ حدوث ترسب لصبغة الهيموسيدرين، اتساع فى الجيوب الدموية وتسرب دموى. لوحظ أيضاً زيادة فى التعبير المناعى لـ CD86 فى سيتوبلازم الخلايا الجذعية. أكثر من ذلك، وجد تفاعل إيجابى ملحوظ للإِلإِنزيم المستحث المخلق لأوكسيد النيتريك وكاسباس ـ (iNOs) بالتز امن مع فيتامين-د فلقد أظهرت أظهرت حفاظاً على التركيب الهستولوجي و الهستوكيميائي مناعي للطحال بشكل كبير.

الخلاصة: تظهر هذه الدر اسة أن فيتامين-د له تأثير وقائى ويمكن أن يخفف التأثيرات الضارة علي الطحال و الجهاز المناعى التي عادة ما نر اها فى حالات للبدانة التى يسبيها اتباع نظام غذائى عالى الدهون. 